\title{
The Constitution of Latvia - A Bridge Between Traditions and Modernity
}

\author{
Kristīne Krūma and Sandijs Statkus
}

\begin{abstract}
The Latvian constitutional system is based on the principle of State continuity after the Soviet occupation, and this is reflected in the reinstatement of the 1922 Constitution (Satversme). Unlike other constitutions in the post-communist area, it is characterised as a laconic and predominantly procedural constitution. However, important amendments were introduced in 1996 and 1998, establishing the Constitutional Court and introducing a catalogue of fundamental rights. The constitutional culture has been influenced by German traditions in constitutional jurisprudence, and the adjudication of legislation on substantive grounds has been stringent. This is particularly evident in the annulment of about $40 \%$ of measures reviewed in the context of the economic crisis (2009-2011). Of particular interest is the constitutional adjudication of the IMF-mandated drastic austerity measures, including a law that envisaged a notable $70 \%$ cut in the payments to pensioners. The Constitutional Court stood out by virtue of strong protection of fundamental rights and the principle of legitimate expectations, with similarities to the approach subsequently taken by the Portuguese Constitutional Court. Additionally, the Constitutional Court underlined that taking international loans is an important matter of public life which must be decided by the legislator, and that the government cannot restrict fundamental rights by assuming international obligations. However, measures such as the European
\end{abstract}

Kristīne Krūma (deceased) was at the time of writing Prorector of the Riga Graduate School of Law. An In Memoriam note has been included in the present book.

Sandijs Statkus is Adviser at the Constitutional Court of Latvia. e-mail: sandijs.statkus@satv. tiesa.gov.lv.

We would like to thank the Max Planck Institute of International and Comparative Law in Heidelberg and Prof. Armin von Bogdandy, and the Centre for Migration Law of Radbound University (Nijmegen) and Prof. Kees Groenendijk for their most useful help and assistance during the preparation of this report.

All websites accessed 15 October 2015. Text submitted 23 April 2015.

\author{
K. Krūma \\ Riga Graduate School of Law, Riga, Latvia \\ S. Statkus $(\square)$ \\ Constitutional Court of Latvia, Riga, Latvia \\ e-mail: sandijs.statkus@satv.tiesa.gov.lv
}

(C) The Author(s) 2019

A. Albi and S. Bardutzky (eds.), National Constitutions in European

and Global Governance: Democracy, Rights, the Rule of Law,

https://doi.org/10.1007/978-94-6265-273-6_20 
Arrest Warrant or Data Retention Directive have not been subject to a constitutional debate. The Constitution contains a range of EU amendments.

Keywords The Constitution of Latvia - Constitutional amendments regarding EU and international co-operation - The Latvian Constitutional Court Constitutional review statistics and grounds - Fundamental rights and general principles of law - European Arrest Warrant - Data Retention Directive IMF austerity programmes - The principle of legitimate expectations and social rights - Parliamentary reservation of law - The role of courts in EU law to ensure compliance $\cdot$ Referendum $\cdot$ Sovereignty $\cdot$ Supremacy

\section{Constitutional Amendments Regarding EU Membership}

\subsection{Constitutional Culture}

1.1.1-1.1.2 The role of the Satversme (the Constitution; hereinafter the Latvian word Satversme will be used) in the Latvian legal order is twofold. First, it has a strong symbolic role. It was adopted in 1922 and regained de facto force upon the restoration of independence. ${ }^{1}$ The backbone of the Satversme has had only minor amendments. However, it has been supplemented with several important articles. For instance, in 1996, a provision on the Constitutional Court; in 1998, Chapter 8 which includes human rights and freedoms; and in 2003, amendments on EU membership were inserted in the Satversme.

Secondly, the Satversme is the fundamental document that addresses primary institutional and procedural issues. The key elements of the Satversme can be summarised as follows: protection of the fundamental principles and values of democracy and the rule of law; the functioning of the parliamentary democracy; guarantees for national sovereignty; ${ }^{2}$ protection of fundamental rights and

\footnotetext{
${ }^{1}$ The Satversme was drafted at the time when the authoritarian regime of Czarist Russia was collapsing. The independence of Latvia was proclaimed on 18 November 1918, just one month before the end of the First World War. There was an ongoing civil war in Russia in 1918, and part of Latvia was occupied by Germany. The complex geo-political situation allowed for the people of Latvia to claim their right to self-determination. At the time, the drafters were inspired by the constitutions of France, Switzerland, Finland, the UK, the US and other states. However, the main example was the Weimar Constitution (Weimarer Verfassung), which was in force in Germany from 1919-1933. References were also made to Russian imperial regulations and legal practice. See the Decisions of the Administrative Department of the Senate from 1922.

${ }^{2}$ See also Constitutional Court Judgment in Case No. 2008-35-01 of 7 April 2009, para. 14.
} 
freedoms; ${ }^{3}$ and the functioning of the division of powers ${ }^{4}$. In terms of the constitutional priorities in practice, it should be noted that more than $80 \%$ of all cases reviewed by the Constitutional Court have concerned provisions of Chapter 8 on fundamental rights.

The Constitutional Court has recognised that the Satversme is essentially a short and laconic yet complex document, i.e. no provision, part or even single word of the Satversme may be regarded as superfluous, because such an interpretation would compromise its structure. ${ }^{5}$

During the initial years after its establishment in 1996, the Constitutional Court relied extensively on a comparative approach to rulings of other constitutional courts. Since regaining independence, Latvia's constitutional culture has been influenced by German traditions in constitutional jurisprudence. The Constitutional Court has also referred to the constitutional provisions and case law of Poland, Canada, USA, Lithuania, the Czech Republic, Slovenia, Finland, Spain and Portugal. ${ }^{6}$ However, this practice has recently changed.

The Court now takes a more careful approach when invoking different international treaties and, when referring to the practice of international courts, attention is paid to the facts of the case, with special caution taken when referring to soft law instruments. For instance, in a case relating to the Civil Procedure Law, the Court stated:

In resolving various issues in the Latvian legal system, the legal regulation of other states cannot be applied directly, except if the law so explicitly provides. Comparative analysis always requires that the different legal, social, political, historical and systemic context be taken into account. ${ }^{7}$

At the same time the Court has remained open to other international law sources, such as the European Convention on Human Rights (ECHR). ${ }^{8}$

According to the Satversme, the Parliament (Saeima) is vested with the most power. Only the people of Latvia have the right to vote for dissolution of the Saeima upon the initiative of the President. In the context of this project it is important to note that legislative power is vested in the Saeima (Art. 64 of the Satversme) and the people. According to Chaps. 2 and 5, the Saeima is the main institution in relations with other constitutional bodies. This means that the Saeima

\footnotetext{
${ }^{3}$ According to the Constitutional Court, the provisions of Chap. 8 establish a threefold obligation: to respect, to protect and to fulfil individual rights.

${ }^{4}$ The Constitutional Court has derived this principle by interpreting Art. 1 of the Satversme. This principle ensures balance and mutual control which fosters temperance of power. Judgment in Case No. 03-05(99) of 1 October 1999, para. 1.

5 Judgment in Case No. 2005-12-0103 of 16 December 2005, para. 17.

${ }^{6}$ See Cases No. 2009-11-01; 2007-01-01; 2002-08-01; 2002-08-01; 2002-21-01; 2002-20-0103.

${ }^{7}$ Judgment in Case No. 2012-06-01 of 1 November 2012, para. 13.3.3. See also Judgments of the Constitutional Court in Cases No. 2007-01-01 of June 2007, para. 24.1., and No. 2010-51-01 of 8 June 2007, para. 17.

${ }^{8}$ For details see Mits 2010, pp. 127-188.
} 
is the body that is directly democratically legitimised to take decisions on the most important issues for Latvia. No other institution can limit the powers of the Saeima, which has many instruments at its disposal to influence other institutions.

\subsection{The Amendment of the Satversme in Relation to the European Union}

\subsection{1-1.2.4 Amendment procedure and constitutional amendment referendums}

The rules on amendment of the Satversme are established in Art. 76, which provides: 'The Saeima may amend the Satversme in sittings at which at least two-thirds of the members of the Saeima participate. The amendments shall be passed in three readings by a majority of not less than two-thirds of the members present.' 9

Further, Arts. 74 and 79 of the Satversme provide that the electorate has direct legislative power if at least a one-half of the voters who participated in the last parliamentary elections vote in a referendum. Art. 78 of the Satversme provides that voters comprising not less than one-tenth of the electorate have the right to submit a fully elaborated draft of an amendment to the Satversme or of a law to the President, who shall present it to the Saeima. If the Saeima fails to adopt such draft without amendments as to its content, the draft shall be submitted to a national referendum. The draft is deemed to be adopted if at least one-half of those who participate vote in favour. Thus, both the Saeima and the people are the main decision-makers when there is a need to amend the Satversme.

There are several provisions of the Satversme which cannot be adopted without the consent of the people of Latvia. According to Art. 77 of the Satversme, if the Saeima amends, inter alia, Arts. $1,2,6^{10}$ or 77 , the amendments come into effect only if confirmed by a referendum. According to Art. 79, an amendment to the Constitution submitted to a referendum shall be deemed adopted if at least one-half of the electorate votes in favour. This means that the fundamental principles of democracy enshrined in Art. 1 as well as the principle of sovereignty provided for in Art. 2 of the Satversme are afforded particular protection. ${ }^{11}$

EU amendments The fundamental articles of the Satversme (i.e. Arts. 1, 2, 3, 4, 6 and 77) have not been amended, neither upon accession to the EU nor subsequently upon amendment of the EU Treaties. The remaining text of the Satversme has been amended on two occasions, with regard to three subject areas in order to comply with EU law: in 2003 upon accession to the EU, and in 2004 to comply with the European Arrest Warrant (EAW) and to ensure the electoral rights of EU citizens.

\footnotetext{
${ }^{9}$ For this and further quotes, the official translation of the Satversme is used. Available at http:// www.vvc.gov.lv.

10 'The Saeima shall be elected in general, equal and direct elections, and by secret ballot based on proportional representation.'

${ }^{11}$ See also the next Section below.
} 
Questions pertaining to the EU in the constitutional context have also been debated at least twice, at the time of the draft Constitutional Treaty and ratification of the Lisbon Treaty as well as when accession to the eurozone was approaching, in connection with the stronger role provided for the EU on the basis of the Treaty on Stability, Coordination and Governance in the Economic and Monetary Union. ${ }^{12}$

The first amendments were introduced in the Satversme on 8 May 2003. Article 68 of the Satversme, which provided that '[a]ll international agreements, which settle matters that may be decided by the legislative process, shall be ratified by the Saeima', was supplemented with the following provisions:

Upon entering into international agreements, Latvia, with the purpose of strengthening democracy, may delegate a part of its State institution competences to international institutions. The Saeima may ratify international agreements in which a part of State institution competencies are delegated to international institutions in sittings in which at least two-thirds of the members of the Saeima participate, and a two-thirds majority vote of the members present is necessary for ratification.

Membership of Latvia in the European Union shall be decided by a national referendum, which is proposed by the Saeima.

Substantial changes in the terms regarding the membership of Latvia in the European Union shall be decided by a national referendum if such referendum is requested by at least one-half of the members of the Saeima.

Article 79 which provides for the procedure for approving amendments to the Satversme by referendum ${ }^{13}$ was also supplemented to provide for a special requirement in the case of accession to the EU or subsequent EU Treaty amendments:

An amendment to the Satversme submitted for national referendum shall be deemed adopted if at least half of the electorate has voted in favour. A draft law, decision regarding membership of Latvia in the European Union or substantial changes in the terms regarding such membership submitted for national referendum shall be deemed adopted if the number of voters is at least half of the number of electors as participated in the previous Saeima election and if the majority has voted in favour of the draft law, membership of Latvia in the European Union or substantial changes in the terms regarding such membership.

When amending the Satversme, the drafters also had to take into account the provisions of Art. 73, which provides:

The Budget and laws concerning loans, taxes, customs duties, railroad tariffs, military conscription, declaration and commencement of war, peace treaties, declaration of a state of emergency and its termination, mobilisation and demobilisation, as well as agreements with other nations may not be submitted to national referendum.

\footnotetext{
12 The treaty entered into force on 1 January 2013. See, http://www.eurozone.europa.eu/euro-area/ topics/treaty-on-stability,-coordination-and-governance-(tscg)/. See also Sect. 2.7.

${ }^{13}$ The general rule is included in Art. 76, which provides that the Satversme can be amended by the Saeima in sittings attended by two-thirds of the Members of Parliament. Amendments must be adopted in three readings by a two-thirds majority of those present.
} 
Therefore, the Satversme does not allow for a referendum to be held on an international treaty. Nevertheless, Arts. 68(4) and 7(2), which allow for a referendum in the case of substantive changes in EU membership, can be qualified as lex specialis in relation to Art. 73 .

The amendments to the Satversme of 8 May 2003 and the subsequent further amendments of 23 September 2004 were adopted in accordance with the procedure envisaged in the above-mentioned Art. 76 of the Satversme (i.e. by the Saeima). The amendments to the Satversme of 8 May 2003 were adopted by an affirmative vote of 88 Members of Parliament (MPs) out of 100 (there were no votes against or abstentions). The amendments of 23 September 2004 were adopted by 74 MPs voting in favour (there were no votes against and only one abstention).

By way of a summary of the amendments, first, Art. 68 allows for the delegation of competences only 'with the purpose of strengthening democracy'. Therefore, a delegation of competences to another state or a non-democratic international institution would be contrary to the Satversme. In this context it is important to establish to what extent competences are delegated or exercised, and whether Latvia remains entitled to withdraw from arrangements which no longer correspond to the initial delegation. The competence to control the compatibility of any delegation with the Satversme lies with the Constitutional Court. ${ }^{14}$

Secondly, Art. 68(2) provides that international treaties providing for delegation of competences should be confirmed by the Saeima with a qualified majority in sittings where at least two-thirds of the MPs participate.

Thirdly, Art. 68(3) states that people have the right to decide not only on joining the EU but also on withdrawal from it. Moreover, the procedure for withdrawal should be identical to the procedure for joining the EU. The three paragraphs of Art. 68 viewed together clearly formulate that a referendum on Latvia's participation in any other international organisation is not necessary. Such membership can be decided by the Saeima alone.

Fourthly, according to Art. 68(4), the people can decide on significant changes in the conditions of membership in the EU if so requested by at least one-half of the Saeima MPs. This allows for it to be established whether the people think that the constitutional structure of the EU is being significantly changed. At the same time, it ensures that referendums are held on substantively important EU issues only. ${ }^{15}$

\footnotetext{
${ }^{14}$ Judgment of the Constitutional Court in Case No. 2008-47-01 of 28 May 2009, para. 11. The Court referred, inter alia, to the Preamble of the 2001 Framework Decision of the Council of the European Union 2001/500/JHA on money laundering, the identification, tracing, freezing, seizing and confiscation of instrumentalities and the proceeds of crime, in which the Council, noting that serious forms of crime increasingly have tax and duty aspects, calls on Member States to provide full mutual legal assistance in the investigation and prosecution of this type of crime, and further recalls that money laundering is at the very heart of organised crime and should be rooted out wherever it occurs. The Court also referred to the Preamble of Directive 2005/60/EC and Directive 2006/70/EC.

${ }^{15}$ See annotation to the draft law on amendments to the Satversme, Reg. No. 158, submitted to the Saeima on 31 January 2003. http://helios-web.saeima.lv/saeima8/reg.likprj. See also Judgment of the Constitutional Court in Case No. 2008-35-01 of 7 April 2009, para. 19.4.
} 
Thus, procedurally, it is the responsibility of the Saeima to decide on the significance of further amendments to the Treaties for the membership of Latvia in the EU. Article 68 requires a significant threshold for a positive decision in the Saeima. Through the textual, historical and systemic interpretation of Art. 68(4), the Constitutional Court has concluded that a referendum on substantive changes to EU membership is non-obligatory, i.e. it depends on the affirmative vote in the Saeima. ${ }^{16}$ The Constitutional Court has noted that although such exercise of the rights of the people provides for certain procedural pre-conditions, the Constitutional Court may not reassess the constitutionality of certain norms of the Satversme because such assessment does not fall within its jurisdiction. ${ }^{17}$ According to the annotation to the amendments, Art. 68(4) does not allow for a referendum to be called in the case of insignificant amendments to EU membership conditions or in the case of transposition of EU legislative acts other than treaties (e.g. directives, regulations and decisions). ${ }^{18}$ However, since accession to the EU, MPs have not requested that a referendum be called on the grounds of significant changes in EU membership requirements.

The second set of amendments was adopted on 23 September 2004 and concerned Arts. 98 and 101 of the Satversme. Article 98 was supplemented with a sentence to bring the Satversme in line with the commitments undertaken in relation to the EAW. This Article now provides that '... A citizen of Latvia may not be extradited to a foreign country, except in the cases provided for in international agreements ratified by the Saeima if by the extradition the fundamental human rights specified in the Constitution are not violated'.

The amendment of Art. 98 was based on Council Framework Decision 2002/ 584/JHA of 13 June 2002 on the European Arrest Warrant and the Surrender Procedures between Member States. ${ }^{19}$ Since Art. 98 of the Satversme prohibited extradition, it was necessary to adopt amendments to comply with EU law. Since the amendments were adopted in the Constitution, there has been no opportunity for the Constitutional Court to express its views on the constitutionality of this Article. Moreover, the Constitutional Court has repeatedly held that it should not be considered as the Court entitled to review the interpretation and application of the law by ordinary courts. Therefore, the only potential avenue for judicial contestation of a ruling of an ordinary court for a person facing extradition is the European Court of Human Rights (ECtHR). ${ }^{20}$

\footnotetext{
${ }^{16}$ Judgment in Case No. 2008-35-01 of 7 April 2009, para. 19.

${ }^{17}$ Ibid., para. 17.

${ }^{18}$ Supra n. 15.

${ }^{19}$ Council Framework Decision of 13 June 2002 on the European arrest warrant and the surrender procedures between Member States (2002/584/JHA), [2002] OJ L 190/1.

${ }^{20}$ See Sect. 2.3.
} 
Article 101 of the Satversme was supplemented to provide for the right of EU citizens to participate in local elections. It now provides as follows:

Local governments shall be elected by Latvian citizens and citizens of the European Union who permanently reside in Latvia. Every citizen of the European who permanently resides in Latvia has the right, as provided by law, to participate in the work of local governments.

The working language of local governments is the Latvian language.

The amendments were based on Art. 22(1) TFEU [Art. 19 TEC], which provides that every citizen of the Union residing in a Member State of which he is not a national shall have the right to vote and to stand as a candidate at municipal elections in the Member State in which he resides, under the same conditions as nationals of that state. ${ }^{21}$

\subsection{Conceptualising Sovereignty and the Limits to the Transfer of Powers}

1.3.1 There have been no amendments that directly address the supremacy and direct effect of EU law. The rules on these matters have been spelt out in the Law of Administrative Procedure and further dealt with by the Supreme Court and Constitutional Court.

The Constitutional Court has stated as follows in relation to the EU:

Upon ratification of the Treaty on Accession of Latvia to the European Union, European Union law became an integral part of the Latvian legal system. Therefore, legal acts of the European Union and interpretation provided by the case law of the European Court of Justice must be taken into account when applying national law. ${ }^{22}$

Thus, the Saeima cannot adopt legal acts which are contrary to its international obligations, including EU obligations. If the Saeima establishes that its international obligations do not comply with obligations under EU law, it must do all that is necessary to remedy the situation. Thus, EU law has become an integral part of the Latvian legal system.

The Constitutional Court has pronounced that Art. 68 of the Satversme prescribes that Latvia must implement its international obligations. According to the Satversme, the Law on International Agreements of the Republic of Latvia and the 1969 Vienna Convention on the Law of Treaties, in any specific case where there is a conflict between international obligations undertaken by Latvia and national norms, international norms must be applied. Upon accession, Latvia delegated part of the competences of its institutions and undertook obligations derived from the

\footnotetext{
${ }^{21}$ Annotation to the draft law 'Amendments to the Satversme of the Republic of Latvia', reg. No. 571, submitted 20 May 2004, available at http://helios-web.saeima.lv/saeima8/reg.likprj.

22 Judgment of the Constitutional Court in Case No. 2004-01-06 of 7 June 2004, para. 7 and in Case No. 2007-11-03 of 17 January 2008, para. 24.2.
} 
EU Treaties. These obligations, inter alia, require the application of EU law in the Latvian legal system. In addition, international obligations which have been confirmed by the Saeima are also binding on the Saeima, which therefore must not adopt legal acts which contradict such international obligations. ${ }^{23}$

All in all, the application of EU law is essential for the successful functioning of the EU and stems from the Art. 4(3) TEU principle of sincere co-operation to which Member States have adhered. Alongside the rhetoric through which they threaten to declare that EU law is not applicable, the constitutional courts often facilitate better compliance with EU law by placing the legislative and constitutional amendments necessary to guarantee full application of EU law, in compliance with the constitution, on the agenda of political bodies. ${ }^{24}$ Notwithstanding the Simmenthal mandate, constitutional courts are comfortable with subjecting the full application of EU law to constitutional reservations, based on concerns regarding fundamental rights protection, ultra vires action by the EU institutions and respect for constitutional identities. These are articulated as warnings according to which the full application of EU law might be limited in cases where EU measures contravene fundamental constitutional principles. These, however, have remained at the level of obiter dicta. ${ }^{25}$

In the case of Treaty amendments, the approach adopted by the Constitutional Court is based on a three step test: (1) whether the international treaty involves the delegation of competences; (2) whether there has been an infringement of fundamental values at the constitutional level; (3) whether a constitutional procedure for legitimisation of the amended Treaty within the national legal order has been observed.

1.3.2-1.3.3 The approach adopted by the Constitutional Court to the delegation of sovereignty is as follows:

The Constitutional Court recognises that the State of Latvia is based on fundamental values such as human rights and fundamental freedoms, democracy, the sovereignty of the State and its people, the division of powers and the rule of law. The State is obliged to guarantee these values and they cannot be infringed by amending the Satversme by law. Therefore, the delegation of competencies cannot violate the rule of law and the basis of an independent, sovereign and democratic republic. Likewise, the EU cannot affect the rights of citizens to decide upon the issues that are essential to a democratic State. Article 2 of the Satversme provides not only for the right to 'the final say' but also for an obligation to assess the membership conditions of an international organisation as such. In this context, the right to 'the initial say' seems even more important. ${ }^{26}$

\footnotetext{
${ }^{23}$ Judgment of the Constitutional Court in Case No. 2004-01-06 of 7 June 2004, para. 7.

${ }^{24}$ Piqani 2012, p. 147.

${ }^{25}$ Ibid., pp. $155-156$.

${ }^{26}$ Judgment in Case No. 2008-35-01 of 7 April 2009, para. 17. The case was brought by a group of voters claiming that the ratification of the Lisbon Treaty should be subject to a referendum. They claimed that the fact that the Saeima refused to organise a referendum violated their rights provided in Art. 101 of the Satversme. The applicants also argued that Art. 2 of the Satversme was infringed. The Court's judgment includes a detailed discussion of a number of provisions introduced by the Lisbon Treaty within the context of Art. 2 of the Satversme. See paras. 16 and 18.1 of the Judgment. The Court noted: 'Already prior to World War II, in international law analysis of the
} 
Therefore, it can be argued that the very notion of sovereignty itself has not been re-interpreted. Sovereignty has always been associated with the capacity to exercise external and internal powers subject to sovereign values. Values attach a normative character to sovereignty reflecting the views dominant in society.

1.3.4 There is no provision in the Satversme providing for its supremacy expressis verbis. However, this can be inferred from the practice of the Constitutional Court and Supreme Court as well as from the legal doctrine.

Neither the Constitutional Court nor the Supreme Court have dealt with any case where the supremacy of EU law has been addressed in relation to the Satversme. It is therefore difficult to construct such a theoretical case. However, since the Satversme is predominantly a procedural constitution, no apparent conflicts with EU law arise. Specific cases of newly delegated competences (abstract control) in the case of Treaty amendments or violations of individual rights (individual or abstract control procedure) might give rise to issues of supremacy in the Constitutional Court.

The Constitutional Court has declared that with regards to domestic acts (including ratified treaties), the place of a particular provision in the legal hierarchy is determined by its legal force, which depends on the institution that has adopted it and the procedure that was followed. The higher the democratic legitimacy of the institution and the higher the required majority for adoption, the higher the rank of the provision. A higher threshold has been set for the cases for which the Satversme was amended. ${ }^{27}$ Therefore, laws adopted pursuant to the procedure prescribed in Arts. 77 and 79 of the Satversme have a higher legal rank than ordinary laws. ${ }^{28}$

\subsection{Democratic Control}

1.4.1 Democratic control of EU matters is primarily exercised by the Saeima and its European Affairs Committee. The Saeima participates in EU decision-making pursuant to the Law on Procedure of the Saeima. Chapter VII ${ }^{1}$, 'Participation of the Saeima in the EU', provides that the European Affairs Committee is responsible for participation in EU affairs, except in cases where the Saeima has decided otherwise. For instance, the European Affairs Committee reviews the positions of Latvia prepared by the Cabinet of Ministers. The Commission is also entrusted with

\footnotetext{
legal consequences that arise when a State undertakes international obligations, sovereignty was treated as the exercise of sovereign rights rather than a restriction thereof. The Permanent Court of International Justice rejected the view that the conclusion of any such treaty according to which a State undertook to perform or refrain from performing certain acts would mean this State's abandonment of its sovereignty. At the same time, the right of entering into international engagements is an attribute of State sovereignty (Affaire du Vapeur "Wimbledon", CPJI Ser A 01 $15,1923,25)^{\prime}$.

${ }^{27}$ See above in relation to the amendment procedures established in Arts. 76 and 79.

28 Judgment of the Constitutional Court in Case No. 2007-10-0103 of 29 November 2007, para. 56.
} 
notifying the EU institutions of the Latvian position on legislative proposals and with transferring documents to other Saeima Committees. There are no other formal rules on the participation of the Saeima in EU affairs. In practice, the procedure is decided by the Committee at the time a new Saeima is elected. The Latvian Members of the European Parliament as well as experts are invited to attend meetings of the Committee. The European Affairs Committee relies on its own information as well as on information from the Cabinet of Ministers. Co-operation is most active when a long-term budget of the EU is debated.

1.4.2 The rules on referendums regarding constitutional amendments and EU membership have been outlined in Sect. 1.2. The EU referendum was not a constitutional amendment referendum, but rather a referendum relating to membership in the EU under the fourth paragraph of the amended Art. 68. Two observations can be made about the results of the referendum. First, since 1990 there have been eight referendums in Latvia. ${ }^{29}$ The referendum in 2003 was the only referendum on EU issues. Of all the referendums held since 1990, the referendum on EU membership had the highest rate of participation, at $71.49 \%$ of all eligible voters. ${ }^{30}$ Secondly, the polarisation between the voters participating was also the highest: EU membership was supported by $66.97 \%$ of voters, but $32.26 \%$ voted against $(0.77 \%$ votes invalid). In five of the other referendums, more than $94 \%$ of the voters voted for the submitted proposal. ${ }^{31}$ The most controversial was the referendum of 1998 on liberalisation of the Citizenship Law, in which $44.98 \%$ of voters voted against liberalisation and $52.54 \%$ were in favour.

\subsection{The Reasons for, and the Role of, EU Amendments}

1.5.1-1.5.3 The amendments to the Satversme before accession to the EU were subject to wide public and political debate, which was followed by a pre-referendum campaign. The debate focused on different aspects of the accession. For instance, questions on the need to amend Art. 2 of the Satversme (on sovereign powers being vested in the people) were posed not only by voters but also by

\footnotetext{
${ }^{29}$ In 1998 on amendments to the Citizenship Law; in 1999 on amendments to the Law on State Pensions; in 2007 on amendments to the Law on National Security and Law on State Security Institutions; in 2008 on amendments to the Satversme and amendments to the Law on State Pensions; in 2011 on dissolution of the Saeima; in 2012 on amendments to the Satversme (concerning Russian as a state language). See http://cvk.lv/pub/public/27094.html.

${ }^{30}$ For instance, the turnout in the 1998 referendum was $69.16 \%$; in $2007-42 \%$; in $2008-42 \%$ (for amendment of the Satversme) and 22.9\% (on the Law on State Pensions); in $2011-44.73 \%$, but in $2012-71.13 \%$. For comparison, in the elections to the European Parliament, the turnout was $41.43 \%$ of eligible voters (2004) and $53.69 \%$ (2009).

${ }^{31}$ In $1999-94.17 \%$ voted for repeal of the Law; in $2007-96.49 \%$ voted for repeal of the Law; in $2008-96.78 \%$ voted for amendments to the Satversme and $96.44 \%$ voted for adoption of the amendments of the Law; in $2011-94.3 \%$ voted for dissolution of the Saeima.
} 
scholars. ${ }^{32}$ Different views were also expressed in the legal doctrine on the notion of sovereignty and on the content of Art. 2 of the Satversme in relation to EU membership. ${ }^{33}$ The dominant view was that sovereignty had not been lost or lessened; quite the opposite - by becoming a member of the EU, Latvia had exercised its sovereignty.

However, there were also other proposals. For instance, professor Ineta Ziemele suggested that the amendments that were introduced to Art. 68 of the Satversme might not be sufficient because they did not ensure parliamentary control over EU activities. She argued that the lack of control might raise problems in the context of division of powers and the legitimacy of the laws applicable in Latvia. The alternative proposal was that all international treaties and EU legislative acts which address legislative issues should be approved by the Saeima. Thus, not only would EU law be recognised explicitly in the Latvian legal system but also the Saeima would preserve parliamentary control. Ziemele also suggested adding Art. 117 to the Satversme, which would provide that ' $[\mathrm{t}] \mathrm{he}$ state protects the rights of EU citizens in accordance with the legislative acts of the EU'. It was argued that this would mean that lawmakers would not have to make amendments to Chapter 8 of the Satversme, even though the rights of EU citizens are constantly increasing and developing. ${ }^{34}$ None of the proposals were adopted.

The political argument was raised that Latvian independence can be properly ensured only by accession to the EU. ${ }^{35}$ Moreover, based on the results of pre-accession monitoring, there were hopes and worries that non-citizens might potentially be granted the status of EU citizen. ${ }^{36}$

Already in 2003, the position of the Constitutional Court towards EU accession was that EU norms are compatible only with a national legal system that corresponds to the requirements set for a democratic state based on the rule of law. ${ }^{37}$ In this sense the Court signalled adherence to the so-called reverse-Solange approach.

The role of constitutions will be discussed further in the final section of the report (Sect. 4), with the suggestion that greater focus ought to be on redefining sovereignty and democracy at the transnational level.

\footnotetext{
32 Buka 2000; Meļkisis 2000; Pleps 2003.

${ }^{33}$ Various proposals were debated in two well-attended conferences of lawyers and experts organised by the Institute of Public Law, on 'The place of EU law in the Latvian legal system and solutions in cases of collision of norms' (2006) and 'The core of constitutional sovereignty' (2007). Conference materials are on file with the authors and available only in Latvian.

${ }^{35}$ See the speech of the Latvian President Vaira Vike-Freiberga on 29 May 2003 during the parliamentary debates. http://www.am.gov.lv/lv/Jaunumi/Runas/2003/2714/.

${ }^{36}$ Krūma 2004, pp. 33-53.

${ }^{37}$ Judgment in Case No. 2002-18-01 of 5 March 2003, para. 6. Latvia concluded an association agreement and received an official invitation to join the EU. Therefore, the laws should be brought in line and political reforms implemented to ensure that Latvia can integrate into the EU. In relation to the elections to the European Parliament, the common principles set out in the EC Treaty should be observed.
} 


\section{Constitutional Rights, the Rule of Law and EU Law}

\subsection{The Position of Constitutional Rights and the Rule of Law in the Constitution}

2.1.1; 2.1.3 Chapter 8 on human rights consists of twenty-seven articles on civic and political rights as well as social, economic and cultural rights. Moreover, other human rights can be derived from other articles of the Satversme. ${ }^{38}$

General principles have not been codified in the Satversme as such. However, there are a considerable number of judgments of the Constitutional Court in which the Court has derived constitutional principles on the basis of the term 'democratic republic' enshrined in Art. 1 of the Satversme. Over the years, more than thirty principles have been declared to have a constitutional rank. For instance, the concept 'rule of law' is not expressis verbis mentioned in the Satversme. However, it has been identified by the Constitutional Court as one of the principles enshrined in Art. 1 of the Satversme under the term 'democratic republic'. Other principles include the division of powers, proportionality, legal certainty (legal expectations) and good governance.

The rights enshrined in the Satversme as well as the principles derived from it are directly applicable, i.e. any court can rely on the provisions of the Satversme irrespective of the provisions of the specific law. The Supreme Court has in administrative cases and civil cases acknowledged that the Satversme should be directly applicable. ${ }^{39}$ For instance, if a person considers that his or her rights of defence envisaged in Art. 92 have been breached, the person has a right to claim compensation by submitting a claim to the court of general jurisdiction. ${ }^{40}$

It can be argued that democratic control is exercised also by the judicial institutions to which individuals and legal persons can submit complaints. In the case of the regular courts, such complaints have resulted in preliminary rulings to the Court of Justice of the European Union (CJEU) or cases referred to the Constitutional Court. Individuals have also turned to the Constitutional Court directly to contest, inter alia, either the constitutionality of a provision of law or other act transposing a directive, or non-compliance with the rules of EU law. ${ }^{41}$

\footnotetext{
${ }^{38}$ Judgment of the Constitutional Court in Case No. 2002-08-02 of 23 September 2002, and in Case No. 2002-18-01 of 5 March 2003. Judgment of the Constitutional Court in Case No. 2009-111-01 of 22 March 2010, para. 19.

${ }^{39}$ For instance, Department of Civil Cases of the Supreme Court, SKC 12/2009, 29 April 2009 (not publicly available) and Department of Administrative Cases of the Supreme Court, SKA-68/ 2013, 22 February 2013, para. 9, available at http://www.tiesas.lv/februaris-10.

40 Judgment of the Constitutional Court in Case No. 2001-07-0103 of 5 December 2001, para. 1.

${ }^{41}$ In other cases, the Court has adopted a usual fundamental rights test: (1) whether the provision has been adopted by law; (2) whether it has a legitimate objective; (3) whether it complies with the principle of proportionality (necessary to achieve the legitimate aim; appropriate to achieve that aim and whether there are alternative, less burdensome measures to achieve the aim in an equally
} 
2.1.2 Article 116 allows for limitations to individual rights. It provides:

The rights of persons set out in Articles ninety-six, ninety-seven, ninety-eight, one hundred, one hundred and two, one hundred and three, one hundred and six, and one hundred and eight of the Constitution may be subject to restrictions in circumstances provided for by law in order to protect the rights of other people, the democratic structure of the State, and public safety, welfare and morals. On the basis of the conditions set forth in this Article, restrictions may also be imposed on the expression of religious beliefs.

However, this norm covers only one-third of the fundamental rights enshrined in the Satversme. Indeed, there are certain fundamental rights which are not subject to restrictions, e.g. the prohibition of torture and inhuman and degrading treatment (Art. 95), the prohibition of censorship (Art. 100), the prohibition of forced labour (Art. 106) and the prohibition of racial discrimination.

At the same time this does not mean that other fundamental rights that are not mentioned in Art. 116 cannot be limited. The Constitutional Court on a number of occasions has acknowledged that although the Satversme does not explicitly provide for cases in which other rights not mentioned in Art. 116 can be restricted, this does not mean that they are absolute. The provisions of the Satversme must be interpreted systematically. This means that if Art. 116 were not applied, this would jeopardise the rights of other persons. The assumption that fundamental rights not mentioned in Art. 116 cannot be subject to restrictions would be contrary to both the rights of other persons enshrined in the Satversme as well as other provisions of the Satversme. ${ }^{42}$

As will be seen in Sect. 2.6, the Constitutional Court has clarified that it assesses the validity of restrictions of civil and political rights as well as social rights on the following criteria: the restrictions must be determined by law, pursue a legitimate aim and comply with the principle of proportionality. ${ }^{43}$

\subsection{The Balancing of Fundamental Rights and Economic Freedoms in EU Law}

2.2.1 No specific issues with regard to the balancing of fundamental rights and economic freedoms have arisen in Latvia. Neither the Constitutional Court nor the Supreme Court have dealt with any cases where the supremacy of EU law has been addressed in relation to the Satversme. Therefore, it is difficult to construct such a theoretical case. By reference to values common to Latvia and the EU, e.g. the rule of law, democracy and human rights, such a collision between the Satversme and

\footnotetext{
effective way). For instance Case No. 2008-34-01 of 13 February 2009, paras. 16-24 and Case No. 2009-85-01 of 30 March 2010, para. 17.

42 Judgment of the Constitutional Court in Case No. 2002-04-03 of 22 October 2002, para. 2 and in Case No. 2004-10-01 of 17 January 2005, para. 7.2.

${ }^{43}$ Mits 2013, p. 19.
} 
EU law is difficult to imagine. It has been accepted that the human rights chapter of the Satversme cannot provide for lower protection in comparison to internationally binding legal acts. Any conclusion to the contrary would run counter to Art. 1 of the Satversme and the rule of law it enshrines. ${ }^{44}$

As was shown in Sect. 1.3.1, the Constitutional Court has in general developed and strengthened interpretation to the benefit of EU law. It has been acknowledged that EU legal acts and CJEU interpretation, as far as they do not encroach upon the fundamental principles of the Satversme, should be taken into account in order to prevent conflicts between Latvian and EU law. When interpreting Latvian law, EU law and its interpretation by the CJEU must be taken into account. ${ }^{45}$

For instance, in a case on the Freeport of Riga in which substantial financial interests were involved, the EU's environmental standards were invoked to declare that territorial planning which aimed at business promotion in certain areas would be in breach of Latvia's obligations under EU law. The Constitutional Court declared that ' $[w]$ hen assessing a legitimate objective, it is necessary to take into consideration the obligations of Latvia as an EU Member State'. The Constitutional Court also stated:

\begin{abstract}
Moreover, upon ratification of the Treaty on Accession of Latvia to the European Union, European Union law has become an integral part of the Latvian legal system. Therefore, legal acts of the European Union and interpretation provided by the case law of the European Court of Justice must be taken into account when applying national law. The same applies to laws on land use planning and protection of the environment.
\end{abstract}

and

... Latvian law must be interpreted so as to avoid any conflicts with the obligations of Latvia towards the European Union, unless the fundamental principles incorporated in the Satversme are affected. ${ }^{46}$ [emphasis added]

For instance, in a case concerning application of the 1965 Convention on Facilitation of International Maritime Traffic, the Constitutional Court pronounced:

Thus it follows from the above laws and international obligations, undertaken by the Republic of Latvia when ratifying the Vienna Convention, that in each particular case, if there arises a discrepancy between international legal norms, ratified by the Saeima and national legal norms of Latvia, the international legal norms shall be applied. Moreover, the

\footnotetext{
44 Judgment of the Constitutional Court in Case No. 2005-02-0106 of 14 September 2005, para. 10. See also Sects. 2.6 and 2.7.

${ }^{45}$ See, for instance, Judgment of the Constitutional Court in Case No. 2007-11-03 of 17 January 2008, para. 25.4 and No. 2011-17-03 of 2 May 2012, para. 13.3. In these cases the Court interpreted copyright and environmental assessment regulation on the basis of provisions of Directive 2001/29/EC and Directive 92/43/EEC as well as the case law of the CJEU.

${ }^{46}$ See Judgment of the Constitutional Court in Case No. 2007-11-03 of 17 January 2008, paras. 24.2. and 25.4., available at http://www.satv.tiesa.gov.lv/upload/judg_2007_11_03.htm. Thus, also with regard to the Natura 2000 territories, the requirements of the directives transposed by Latvia and the interpretation of the directives established in the case law of the European Court of Justice should be observed.
} 
international obligations, undertaken by Latvia on the basis of international agreements, confirmed by the Saeima, are binding also on the Saeima itself. It may not adopt legal acts, which contravene the above obligations. ... Any person applying legal norms, including a court, when establishing a discrepancy between an international legal norm and a national legal norm of Latvia, shall apply the international legal norm. ... When applying the legal norms of the European Union (Community) the institution and the court shall take into consideration the jurisprudence of the European Court of Justice. ${ }^{47}$

Similarly, according to Art. 15(4) of the Law on Administrative Procedure, EU law is applicable according to the hierarchy of normative acts. When applying EU law provisions, the relevant institution or court must observe the case law of the CJEU. The Supreme Court has held that CJEU rulings must be applied when interpreting provisions through historical and systemic interpretation. ${ }^{48}$ The same approach has been adopted by the Supreme Court in civil law cases. It has for example interpreted labour law in accordance with Directive 91/533/EEC in relation to the obligation to inform an employee of termination of a contract in writing. $^{49}$

At the same time, in a case concerning the prevention of laundering of the proceeds from crime and financing terrorism and the interpretation of the Directive 2005/60/EC and Directive 2006/70/EC, the Constitutional Court has stated that the Court should verify whether interpretation of the CJEU is indispensable:

[E]ven if the Court of Justice were to conclude that Directive 2005/60/EC requires refraining from the execution of transactions for a certain period after the persons subject to the law have reported to the Control Office, this would not affect the outcome of the case because the Constitutional Court should verify compliance of the established procedure with the Satversme. ${ }^{50}$

Systems might overlap but be capable of compatibility. This is even more true since the adoption of the EU Charter of Fundamental Rights as a legally binding instrument. Consequently, the overlapping systems develop over time through the process of judicial discourse and without predetermined finality. ${ }^{51}$

\footnotetext{
${ }^{47}$ See Judgment of the Constitutional Court in Case No. 2004-01-06 of 7 July 2004, paras. 6 and 7 of reasons, available at http://www.satv.tiesa.gov.lv/?lang=2\&mid=19.

48 Judgment of the Supreme Court in Case No. SKA-216 of 23 November 2004, para. 10. Judgments and decisions of the Department of Administrative Cases of the Supreme Court of the Republic of Latvia, Riga: Tiesu namu Agentüra, 2005, pp. 571-579; Judgment of the Supreme Court in Case No. 162/2007 of 10 May 2007, para. 8.

${ }^{49}$ Civil Department of the Supreme Court, Judgment in Case No. SKC-388/3012 of 4 April 2012, para. 11. Not published.

${ }^{50}$ Judgment of the Constitutional Court in Case No. 2008-47-01 of 18 May 2009, para. 15.2. The English translation is available at the Court's website at http://www.satv.tiesa.gov.lv/upload/judg 2008_47_01.htm.

${ }^{51}$ Krūma 2009, p. 155.
} 


\subsection{Constitutional Rights, the European Arrest Warrant and EU Criminal Law}

2.3.1-2.3.6 There has been no public debate on the European Arrest Warrant Framework Decision or the EU Data Retention Directive ${ }^{52}$ in Latvia. A few articles have been published on the EAW, but they have been quite positive. Moreover, the amendments to the Satversme (see Sect. 1.2) might be why the EAW has never been contested before the Constitutional Court.

The provisions of Art. 92 of the Satversme have served as a basis for the Constitutional Court to identify principles such as nullum crimen, nulla poena sine lege and ne bis in idem, ubi ius ibi remedium in the domestic context in areas not related to the EAW. ${ }^{53}$ The articles providing for defence rights in the Latvian Constitution are as follows:

\section{Article 92}

Everyone has the right to defend his or her rights and lawful interests in a fair court. Everyone shall be presumed innocent until his or her guilt has been established in accordance with law. Everyone, where his or her rights are violated without basis, has a right to commensurate compensation. Everyone has a right to the assistance of counsel.

\section{Article 94}

Everyone has the right to liberty and security of person. No one may be deprived of or have their liberty restricted, otherwise than in accordance with law.

The more detailed regulation arising from Framework Decision 2002/584/JHA is enshrined in Chaps. 65 and 66 of the Law on Criminal Procedure. According to Art. 714(4) of the Law, a person cannot be extradited if the crime in question is not punishable in Latvia or has not been committed in the state which requests extradition. A person also cannot be extradited to a country which does recognise the behaviour in question to be criminal.

According to defence lawyer Aldis Alliks, there are insufficient guarantees in Art. $715\left(3^{(1)}\right)$ of the Law, which does not allow for sufficient protection for a person convicted in another EU Member State in absentia. The provision allows a convicted person to become acquainted with the ruling but does not provide the right to defence. Alliks has also noted that when adopting this Article, Latvia did not make use of the freedom of action envisaged in Art. 2 of Framework Decision 2009/299/ TI amending decisions 2002/584/JHA, 2005/214/JHA, 2006/783/JHA, 2008/909/

\footnotetext{
52 Directive 2006/24/EC of the European Parliament and of the Council of 15 March 2006 on the retention of data generated or processed in connection with the provision of publicly available electronic communications services or of public communications networks and amending Directive 2002/58/EC, [2006] OJ L 105/54.

53 Judgments of the Constitutional Court in Cases No. 2008-09-0106 of 16 December para. 4.2., No. 20120-02-0106 of 18 October 2012, para. 11.2., No. 2004-06-01 of 11 October 2004, para. 21.
} 
JHA and 2008/947/JHA. ${ }^{54}$ Aside from this there have been no major problems in applying the EAW. ${ }^{55}$

The Public Prosecutor has informed the Experts that Latvia does not verify the evidence in an EAW case but only requests a comprehensive description of the crime committed. There are also on-going debates on the need to ensure the assistance of a lawyer before a person is extradited and to compensate a person for expenses related to his or her return trip home if the person is found innocent. ${ }^{56}$

Latvia provides consular assistance, which is an obligation derived not only from the Satversme but also from the Vienna Convention on Consular Relations. This assistance is evidenced by the practice of the consular institutions. ${ }^{57}$

The effectiveness of the EAW largely depends on mutual trust between the courts and the EU Member States regarding the judicial systems and the protection of the fundamental rights of persons who are extradited when they are in custody. ${ }^{58}$ Latvia has had differing experiences in this respect. For instance, a number of Latvian citizens have been subject to trials in the UK and Ireland for serious crimes. At the same time, an Austrian court refused to extradite a Latvian citizen who had been accused of serious crimes. He was placed under arrest in Latvia and subsequently released and ordered not to leave the country. Nevertheless, he fled to Austria, which refused to extradite him on the grounds of his health. ${ }^{59}$

Since all EU Member States are parties to the ECHR and the EU is about to accede to the ECHR, the application of the EAW could be based on the principles established by the ECtHR. ${ }^{60}$ Moreover, implementing fundamental rights monitoring as suggested by the European Commission and the Council of Ministers in '[a]n EU internal strategic framework for fundamental rights: joining forces to achieve better results' could help increase mutual trust and streamline fundamental rights practices. ${ }^{61}$

\footnotetext{
${ }^{54}$ OJ L 81/24, 27 March 2009.

${ }^{55}$ Information provided by defence lawyer Aldis Alliks, 2 September 2014. Issues related to the EAW were discussed by judges during a conference in 2013. See Plaksins 2013.

${ }^{56}$ An e-mail exchange between the Experts and Ms. Una Brenča, Chief Prosecutor of the Division of International Co-operation, Department of Functional Analysis and Management, 30 September 2014.

${ }^{57}$ CARE, Citizens Consular Assistance Regulation in Europe. Report on Latvia http://www. careproject.eu/database/browse_euc.php\# and consolidated report available at http://www. careproject.eu/images/stories/ConsularAndDiplomaticProtection.pdf. This contains information on Latvian practice on consular assistance to Latvian citizens and non-citizens abroad.

${ }^{58}$ See Decision of the Chamber of the Constitutional Court on Applications 72/2013, 73/2013, 74/ 2013 on 31 May 2013, 138/2013 on 31 July 2013, as well as Judgment of the ECtHR Calovskis v. Latvia, no. 22205/13, 24 July 2014.

${ }^{59}$ For details see http://www.tvnet.lv/zinas/kriminalzinas/495427-kukuldosana_apsudzetais_ vaskevics_joprojam_arstejas_austrija.

${ }^{60}$ See, for instance, Judgment of the ECtHR in Čalovskis v. Latvia, supra n. 58, paras. 129-133 and 155-158. The case has been appealed to the Grand Chamber.

${ }^{61}$ See European Union Agency for Fundamental Rights (FRA) Annual Report 2013. Luxembourg 2014. http://fra.europa.eu/sites/default/files/annual-report-2013-focus_en.pdf.
} 


\subsection{The EU Data Retention Directive}

2.4.1 Issues related to the Data Retention Directive have not been discussed in Latvia, and there is no information on any related court cases. The implementation of the Directive has also not been contested in the Constitutional Court. In terms of the constitutional provisions, Art. 96 provides that '[e]veryone has the right to inviolability of his or her private life, home and correspondence'.

\subsection{Unpublished or Secret Legislation}

2.5.1 No issues regarding unpublished or secret legislation have arisen in Latvia. The Constitutional Court has discussed the issue of unpublished documents serving as a basis for austerity measures and the unavailability of the records of the negotiations with the IMF and the EU. ${ }^{62}$ However, since legislation implementing the agreed measures was adopted in accordance with the required legislative procedure, there are no grounds to delve further into this issue (see in greater detail Sect. 2.7).

If there were a case involving unpublished or secret legislation, the Constitutional Court would have to pronounce that the norm had not been established by law and was ultra vires, as an important aspect of the principle of the rule of law.

\subsection{Rights and General Principles of Law in the Context of Market Regulation: Property Rights, Legal Certainty, Non-retroactivity and Proportionality}

General principles of law are applied on the basis of the same methodology as written norms. However, if an individual applies to the Constitutional Court, he or she must show that there has been a prima facie breach of a fundamental right provided in Chap. 8 of the Satversme. According to the Law on the Constitutional Court, a case cannot be initiated on the basis of an individual application solely based on a principle derived from Art. 1 of the Satversme. In more than one-half of such cases (that refer to Art. 1), reference has been made to the principle of legitimate expectations in combination with a fundamental rights provision. The main objective of the principle of legitimate expectations is to protect the rights of a person in cases where provisions of law might potentially cause a deterioration of the situation of the individual. ${ }^{63}$

\footnotetext{
62 Judgment of the Constitutional Court in Case No. 2009-43-01 of 21 December 2009, paras. 26 and 30.1 .

63 Judgment of the Constitutional Court in Case No. 2006-04-01 of 8 November 2006, para. 21. Another article on the basis of which several principles have been derived is Art. 92 (right to a fair trial).
} 
The principle of legitimate expectations was central to the pensions cases concerning cuts imposed due to the financial crisis, which will be explored in Sect. 2.7.

It may be worth noting that in the Estonian Sugar case mentioned in the Questionnaire, the Latvian government intervened and supported some of the claims regarding the breach of the general principles of law by the imposition of the EU fine. The Latvian Government in particular raised the issue of the breach of legitimate expectations ${ }^{64}$ and the breach of defence rights in contesting the EU fine calculations, ${ }^{65}$ and pointed out that the objective of EU Regulation 60/2004, rather than burdening the state budgets of the new Member States, was to burden the budgets of undertakings that had bought sugar for speculative purposes. Upon examining how the Commission calculated the subsequent fine set out in Regulation 832/2005, the Latvian Government was concerned that it was impossible to achieve the objectives of Regulation 60/2004. ${ }^{66}$

However, EU law has enhanced the protection of property rights in cases concerning bank insolvency where EU law has played an important role. For instance, in a case on protection of the property rights of minority shareholders, the Constitutional Court had to address the principles derived from Directive 77/911/EEC. ${ }^{67}$ The Court noted that EU membership does not mean that norms included in the directive will in all cases influence the scope of the fundamental rights included in the Satversme. It further stated:

In the present matter, it is necessary to take into account the special character and place in commercial law of Directive 77/91/EEC as an instrument establishing minimum standards for protection of shareholders' rights. Article 25 and Article 29 of the above mentioned Directive have been elaborated taking into account the protection of the fundamental rights of shareholders effected in the Member States.

and

It has already been indicated that Article 105 of the Satversme shall be interpreted in conjunction with the obligations of Latvia as a Member State of the EU and particularly in conjunction with Directive 77/91/EEC. The Constitutional Court has already concluded that there is no appeal against judgments of the Constitutional Court; therefore the Constitutional Court will verify whether the Court of Justice has already interpreted the above mentioned issue, whether that which has been established in the Directive is clear enough not to cause any reasonable doubt, and whether it is necessary to request a preliminary ruling from the CJEU. ${ }^{68}$

\footnotetext{
${ }^{64}$ Paragraph 28; Case T-324/05 Estonia v. Commission [2009] ECR II-03681, paras. 351-352.

${ }^{65}$ Ibid., para. 349.

${ }^{66}$ Ibid., para. 345.

${ }^{67}$ Judgment of the Constitutional Court in Case No. 2010-71-01 of 19 October 2011.

${ }^{68}$ Judgment of the Constitutional Court in Case No. 2008-47-01 of 28 May 2009, paras. 13.3 and para. 24, with reference to several CJEU rulings including in Case C-441/93 Pafitis and others [1996] ECR I-01347, paras. 24, 38 and 39.
} 
At the same time the Constitutional Court concluded that international norms do not prohibit the Member States from establishing a higher level of protection of rights in their constitutions, and there is no need to ask for a preliminary ruling.

Thus, application of EU law and its principles occurs in specific contexts, but the Constitutional Court has repeatedly emphasised that national standards can offer higher protection.

\subsection{The ESM Treaty, Austerity Programmes and the Democratic, Rule-of-Law-Based State}

2.7.1-2.7.3 Austerity programme In 2009, Latvia was hit by an economic crisis, which was partly exacerbated by the bankruptcy of a systemically important bank in Latvia that had significant external exposure. ${ }^{69}$ In addition there was extensive use of bank loans and overspending of public funds in different areas of governance. In the aftermath of the crisis, the Constitutional Court was flooded with a number of constitutional claims, which have been labelled as 'crisis cases'. During 20092011, the Constitutional Court adopted more than 25 such judgments. ${ }^{70}$ These cases concerned a wide variety of issues, such as the reduction of pensions, ${ }^{71}$ indexation of pensions during the crisis, ${ }^{72}$ reduction of benefits for parents of new-born children, ${ }^{73}$ reduction of food rations for inmates,${ }^{74}$ the sale of pledged immovable

\footnotetext{
${ }^{69}$ For a discussion of the economic crisis and its escalation see Mits 2013 and Aslund and Dombrovskis 2011. On the role of the bankruptcy of a major systemic bank in Latvia with significant external exposure as a reason facilitating economic crisis, see http://www.reverta.lv/ files/PDF\%20finansu/2008_parskats/2008_5_lv.pdf.

${ }^{70}$ See n. 69. During that time, the financial deficit of the consolidated state budget reached 643 million EUR or approximately $3.5 \%$ of the Gross Domestic Product, and the prognosis was that the deficit might reach 1.8 billion EUR or approximately $9.5 \%$ of the Gross Domestic Product by the end of 2009. As a consequence, both the performance of the functions of the state and the possibility of economic recovery in the foreseeable future were put at risk. The state was compelled to turn to international institutions in order to obtain loans for the stabilisation of the economic situation and the financial system of the Republic of Latvia. The loans were conditional on a reduction of state budget expenditures by more than 700 million EUR. Consequently, the budget for the year 2009 had to be modified, reducing expenditures in this amount. Other alternatives for cutting expenditure, such as devaluation of the national currency, were regarded as unacceptable. With the adoption of the impugned provisions, the planned social insurance special budget for the year 2009 was more than 88 million LVL.

71 Judgment of the Constitutional Court in Case No. 2009-43-01 of 21 December 2009. See also Case No. 2009-76-01 of 31 March 2010, Case No. 2009-88-01 of 15 April 2010, and Case No. 2009-86-01 of 21 April 2010. See also Judgment in Case No. 2010-29-01 of 18 February 2011.

72 Judgment of the Constitutional Court in Case No. 2009-08-01 of 26 November 2009.

73 Judgment of the Constitutional Court in Case No. 2009-44-01 of 15 March 2010.

${ }^{74}$ Judgment of the Constitutional Court in Case No. 2009-69-03 of 9 March 2010.
} 
property at auction, ${ }^{75}$ state aid to producers of bio-fuels, ${ }^{76}$ review of compensation in cases of invalidity, ${ }^{77}$ reduction of subsistence benefits for children, ${ }^{78}$ introduction of a capital gains tax for deposits in banks and private pension funds, ${ }^{79}$ reduction of compensation for workers in cases of insolvency, ${ }^{80}$ support for credit institutions in cases of crisis ${ }^{81}$ and the reduction of judges' remuneration. ${ }^{82}$ To summarise, most of the cases related to the reduction of payments from the state budget, and problems triggered by the crisis related to differences in the formerly applicable rules and the new rules adopted in reaction to the crisis. ${ }^{83}$

In the context of the 'crisis cases', the Constitutional Court reviewed more than sixty laws adopted by the Saeima or regulations adopted by the Cabinet of Ministers with regard to their compliance with the Constitution. However, only $40 \%$ were declared unconstitutional. This is the same percentage as, for instance, during 2011-2015. ${ }^{84}$ This can be explained by the fact that in crisis situations, the legislature and executive are given more freedom of action in relation to measures which aim to stabilise the financial situation. The overall aim of such measures is to ensure the well-being of the society at large. Even in the cases in which a regulation was declared unconstitutional, the Court gave the legislature a considerable time limit to remedy the situation, considering the financial consequences of its rulings. For instance, in Case No. 2009-43-01, it was acknowledged that withheld pensions should be compensated for within five and a half years after the adoption of the judgment. $^{85}$ In Case No. 2010-12-03, it was established that producers of bio-fuels should receive compensation within four years after adoption of the judgment. ${ }^{86}$

At the same time it should be mentioned that the financial consequences of some of the judgments were important for the state budget. ${ }^{87}$

\footnotetext{
75 Judgment of the Constitutional Court in Case No. 2010-08-01 of 24 November 2010.

${ }^{76}$ Judgment of the Constitutional Court in Case No. 2010-12-03 of 27 October 2010.

77 Judgment of the Constitutional Court in Case No. 2010-17-01 of 29 October 2010.

78 Judgment of the Constitutional Court in Case No. 2010-18-01 of 10 January 2011.

${ }^{79}$ Judgment of the Constitutional Court in Case No. 2010-59-01 of 13 April 2011.

${ }^{80}$ Judgment of the Constitutional Court in Case No. 2010-69-01 of 10 June 2011.

${ }^{81}$ Judgment of the Constitutional Court in Case No.2010-71-01 of 19 October 2011 and Case No. 2010-60-01 of 30 March 2011.

${ }^{82}$ For instance Judgment of the Constitutional Court in Case No. 2009-11-01 of 18 January 2010 and Case No. 2009-111-01 of 22 June 2010.

${ }^{83}$ Skudra 2010, pp. 41-43.

${ }^{84}$ As of 20 December 2011, the Court has reviewed 82 norms in 50 cases. Of these norms, 32 were declared unconstitutional (39\%).

85 Judgment of the Constitutional Court in Case No. 2009-43-01 of 21 December 2009, para. 35.3. See Sect. 2.6.

${ }^{86}$ Judgment of the Constitutional Court in Case No. 2010-12-03 of 27 October 2010, para. 17.

${ }^{87}$ For instance, to apply the Judgment in Case No. 2009-43-01 of 21 December 2009, approximately 105 million EUR were required from the state budget. See http://www.apollo.lv/zinas/ saeima-nolemj-ietureto-pensiju-dalu-atmaksat-aprili/440829. This constituted about $2 \%$ of the income planned for the 2010 budget.
} 
Pensions cases One case that should be described in detail is the leading case on the reduction of pensions, which was linked to issues of global and EU financial governance. The petitions in this case affected a very large segment of the population. These cases also stood out due to the interpretation of the Court regarding the justiciability of economic and social rights, and decisions on international loans. ${ }^{88}$ The case was prompted by the Law on Disbursement of State Pensions and State Allowances in the Period 2009-2012. According to the Law, the total amount of payments to be paid out to pensioners had to be cut by $10 \%$, which resulted in a notable $70 \%$ cut in the payments to pensioners who continued to work. ${ }^{89}$ The Constitutional Court dealt with the constitutionality of the law in the light of Arts. 1 (democracy and legitimate expectations), 91 (principle of equality), 105 (property rights) and 109 (social security rights) of the Satversme.$^{90}$ The main question was to what extent the contested provisions fell within the scope of Art. 109 of the Satversme and its social guarantees. Article 109 of the Constitution provides that ' $[\mathrm{e}]$ veryone has the right to social security in old age, for work disability, for unemployment and in other cases as provided by law'. The Court noted that the principles derived from Art. 1, i.e., legitimate expectations and proportionality, might have a different meaning depending on the area of regulation. This might limit the control exercised by the Constitutional Court and the freedom of action exercised by the Saeima. ${ }^{91}$ The same applies in relation to Art. 91, with regard to which the Constitutional Court has repeatedly stated that when ascertaining whether any legal provision of the Law on State Pensions contradicts the principle of equality, one has to take into account the area that the impugned provision falls into. The principle of equality usually applies along with other fundamental rights, especially because often a case cannot be adjudicated on the basis of this principle alone. The rights established in Art. 91 of the Constitution are 'relative'. Namely, although they stipulate equal treatment, they do not reveal the nature of such treatment. ${ }^{92}$

Although the Constitutional Court has stated that the right to receive a pension is deemed a property right, when determining whether a legal provision complies with Art. 105, one has to take into account whether the case falls rather into the area of social rights (Art. 109). In cases involving social rights, Art. 105 does not offer the same protection as in cases involving the restriction of property rights in their 'classic' sense. ${ }^{93}$ The Constitutional Court acknowledged that a wide freedom of

\footnotetext{
${ }^{88}$ Mits 2013, pp. 13 and 11-53. See also Sects. 2.7 and 3.5.

${ }^{89}$ Article 9 of the Disbursement Law obliged the Cabinet of Ministers to reconsider the validity of the disbursement restrictions stipulated by this law twice a year and to submit to the Saeima either a report concerning the continuation of the restrictions, or, in the case of need, a draft law concerning their full or partial revocation accordingly.

${ }^{90}$ See Judgment of the Constitutional Court in Case No. 2009-43-01 of 21 December 2009.

${ }^{91}$ See for instance Judgment of the Constitutional Court in Case No. 2006-04-01 of 8 November 2006, paras. 15.2 and 15.3.

92 Judgment of the Constitutional Court in Case No. 2005-08-01 of 11 November 2005, paras. 5 and 6.1 and Judgment in Case No. 2006-04-01 of 8 November 2006, para. 15.

93 Judgment of the Constitutional Court in Case No. 2007-01-01 of 8 June 2007, paras. 20 and 21.
} 
action should be granted to the state in respect of property rights in the area of social rights. The Constitution does not guarantee a specific amount of pension. However, Art. 109 of the Constitution provides for more guarantees in the social field.

The Court referred to the international commitments of Latvia. ${ }^{94}$ Among others, the Court referred to Art. 9 of the International Covenant on Economic, Social and Cultural Rights ${ }^{95}$ and the ECHR. ${ }^{96}$ It concluded that the reduction of the pension disbursement amount prescribed by the impugned legal provisions had to be considered in the context of the principles derived from Art. 1 of the Satversme and Protocol 1, Art. 1 of the ECHR, taking into account both the protection of property rights and the Latvian pension system.

The methodology applied by the Court was the same as applied to determine the validity of restrictions of civil and political rights: the restriction must be determined by law, pursue a legitimate aim and must comply with the principle of proportionality. ${ }^{97}$

At the same time, the Constitutional Court acknowledged that the political dimension of decisions taken by the state concerning the enactment of social rights is usually significant. Decisions in this area are made not so much following legal considerations as political ones. ${ }^{98}$ In the area of social rights, it is not always possible to draw an exact dividing line between legal and political considerations, and the Constitutional Court should refrain from judging political matters, for this is primarily the area of authority of a democratically legitimated legislator. ${ }^{99}$

The Court acknowledged that on the one hand, the implementation of fundamental rights depends on the resources at the disposal of the state and society. The state should be allowed wide freedom of action when deciding matters relating to

\footnotetext{
94 Judgment of the Constitutional Court in Case No. 2007-03-01 of 18 October 2007, para. 11. Article 89 of the Constitution, stating that the State shall recognise and protect fundamental human rights in accordance with the Constitution and international agreements binding upon Latvia. This article clearly shows the constitutional legislator's intention to harmonise the constitutional provisions concerning human rights with the international regulation of human rights; Judgment of the Constitutional Court in Case No. 2007-24-01 of 9 May 2008, para. 11.

${ }^{95}$ UN Committee on Economic, Social and Cultural Rights, General Comment No. 19. The right to social security, E/C.12/GC/19 4 February 2008, para. 11. Limburg Principles on the Implementation of the International Covenant on Economic, Social and Cultural Rights, U.N. Commission on Human Rights, U.N. ESCOR, 43d Sess., U.N. Doc. E/CN.4/1987/17. Even if a country has a substantial deficiency of financial resources, it is obliged to protect the weakest members of the society (see UN Committee on Economic, Social and Cultural Rights, General Comment No.3). The nature of States parties obligations, E/1991/23 14 December 1990, para. 12; UN Committee on Economic, Social and Cultural Rights, General Comment No. 6. The economic, social and cultural rights of older persons, E/1996/22 8 December 1995, para. 17.

${ }^{96}$ The ECtHR adjudicates on matters pertaining to social security and social assistance in the light of property rights as they are interpreted in Protocol 1, Art. 1 of the Convention. See ECtHR Judgment in Stec and Others v. the United Kingdom [GC], nos. 65731/01 and 65900/01, § 51, ECHR 2006-VI; and Moskal v. Poland, no. 10373/05, § 61, 15 September 2009.

${ }^{97}$ Mits 2013, p. 19.

98 Judgment of the Constitutional Court in Case No. 2006-04-01 of 8 November 2006, para. 16. ${ }^{99}$ Ibid.
} 
social rights. In certain cases, an economic crisis can develop to the point where freedom of action must be granted to the legislator to enable the implementation of remedial measures - even if the latter might infringe on the fundamental rights established by the Satversme. ${ }^{100}$ The impugned provisions were adopted in circumstances of rapid economic decline in Latvia. State budget revenues were decreasing and unemployment was growing, bringing about an increase in social insurance expenditure. In the second quarter of 2009, Latvia underwent the most rapid economic decline in the European Union. ${ }^{101}$ The austerity measures hit many sectors, and public expenditure was cut by $25 \%$, including wages in the public sector. Latvia had to borrow some 7.5 billion EUR.

However, on the other hand, the state is not entitled to refuse to enact measures to protect the core rights related to social protection in the Constitution. In this case the rights are not just declaratory, and their protection has a constitutional value in Latvia. ${ }^{102}$ The Constitutional Court pointed out that even if the state reduces the pension disbursement amounts for a period of time in a situation of rapid economic recession, there is still a definite body of fundamental rights from which the state cannot derogate. In this context, it is essential to determine whether the substance of the right of pension recipients to social security has been infringed. ${ }^{103}$ In its judgments, the Constitutional Court has repeatedly adjudicated the constitutional compliance of legal provisions pertaining to social rights, affirming that the state is responsible for the system of social and economic protection and its

${ }^{100}$ In this context, the Court referred to the concurring opinion of judge Thomassen in Kjartan A'smundsson v. Iceland, no. 60669/00, ECHR 2004-IX.

${ }^{101}$ Thus, for instance, the revenues of the consolidated state budget during the first six months of 2009 were $15 \%$ lower than those of the same time period in 2008. The Ministry of Welfare indicated that the actual expenditures of the social insurance special budget were approximately 122 million EUR higher than revenues during the first six months of 2009. At the same time, the rapid increase of wages during the preceding years had brought about an increase in the expenditures of the social insurance special budget. At the same time, the expenditures of the consolidated state budget during the first six months of 2009 were $7.2 \%$ higher than those of the same time period in 2008. The drop in the Gross Domestic Product in comparison with the first six months of 2008 was $18.7 \%$. Concerning the need to balance the revenues and expenditures of the social security system, the Saeima indicated that, as a result of the economic crisis, wages had decreased and unemployment increased. Consequently, the social insurance special budget revenues dropped. The number of socially insured persons had also decreased by $12.3 \%$. The drop in revenues persisted also in the third quarter of 2009 , reaching $18.4 \%$. See http://www.csb.gov.lv/ $\mathrm{csp} / \mathrm{content} /$ ?cat=244. The projected amount of the Government's external debt for the second half of 2009 was approximately $33.2 \%$ of the Gross Domestic Product, and it had increased by approximately $70 \%$ over 2008, see http://ec.europa.eu/economy_finance/pdf/2009/ autumnforecasts/lv_en.pdf. See also Sect. 2.7.

102 Judgment of the Constitutional Court in Case No. 2000-08-0109 of 13 March 2001.

${ }^{103}$ See Judgment of the Constitutional Court in Case No. 2009-43-01 of 21 December 2009, para. 31, and ECtHR Judgment in Kjartan Ásmundsson v. Iceland, supra n. 100, para. 39. See also notes 73-75. 
maintenance. ${ }^{104}$ When altering the social security system, the legislator is bound by constitutional guarantees. The Court noted that the haste in the preparation and adoption of the impugned provisions, as well as the fact that the public had not been duly and timely informed prior to the adoption of these provisions, should be viewed negatively. ${ }^{105}$

The Constitutional Court held that a pension disbursement reduction can have a legitimate end - to solve financial problems in the social budget. There is a need to preclude a deficit in the state pension budget as well as a need to ensure that pension disbursements continue in the future. ${ }^{106}$ The Court noted that the sustainability of the pension system is closely related to the overall economic situation in the state. Thus, in circumstances of major economic recession, the legislator should act as swiftly, concertedly and decidedly as possible. However, the economic situation in the state, or the need to reduce the budget deficit, in the absence of other legitimate ends, cannot serve as an overarching justification for the state to restrict rights that have previously been granted. ${ }^{107}$ Therefore, the task of the Court was to determine whether the impugned provisions were reasonable and brought about a short-term or long-term satisfaction of needs as well as whether the provisions in question were transparent and had been made public. ${ }^{108}$

The Saeima and the Cabinet of Ministers repeatedly referred to the liabilities to international creditors as one of the reasons for the adoption of measures to reduce pensions. On 19 December 2008, a Stand-By Agreement was made between Latvia and the IMF. On 20 January 2009, a Memorandum of Understanding between the EU and Latvia was concluded, which was followed by a Loan Agreement between the EU, Latvia and the Bank of Latvia. ${ }^{109}$ However, the information presented to the Court was contradictory on the question of to what extent international creditors had specifically asked for pensions to be cut. ${ }^{110}$

\footnotetext{
104 Judgment of the Constitutional Court in Case No. 2001-11-0106 of 25 February 2002, para. 1 and Case No. 2005-19-01 of 22 December 2005, para. 9.

105 Judgment of the Constitutional Court in Case No. 2009-08-01 of 26 November 2009, para. 17.2.

106 Judgment of the Constitutional Court in Case No. 2001-12-01 of 19 March 2002, para. 2. Judgment of the Constitutional Court in Case No. 2005-08-01 of 11 November 2005, para. 8 and Case No. 2009-43-01 of 21 December 2009, para. 27.2.

107 Judgment of the Constitutional Court in Case No. 2009-43-01 of 21 December 2009, para. 27.2. The decrease of budget expenditures reached by means of the impugned provisions was approximately $17.4 \%$ or one-sixth of the total reduction of the consolidated state budget.

${ }^{108}$ Ibid., para. 29.2. See also Langa 2009, p. 33.

${ }^{109}$ See also Mits 2013, pp. 14-15.

${ }^{110}$ See Judgment of the Constitutional Court in Case No. 2009-43-01 of 21 December 2009, para. 30.2.2. The Ministry of Welfare explained that the Disbursement Law Draft had to be drawn up in a limited period of time, and it was not possible to consider alternatives due to a lack of time. The Cabinet of Ministers, in turn, explained that debates concerning the required reduction of the state budget of over 700 million EUR were extremely difficult. Other alternatives to the reduction of pensions were considered in these debates. Yet, as a result, an agreement was reached only with regard to one specific solution. Moreover, it would not be rational to discuss other solutions during
} 
The Constitutional Court established that the original documents related to the receipt of the international loans did not contain information that could be associated with a requirement to adopt the impugned provisions. ${ }^{11}$ Although the international creditors prescribed the main goals to be achieved by the state, the choices of the most suitable and appropriate means for attainment of these objectives were left to the state's own discretion. Moreover, the obligations undertaken by the Government with respect to the international creditors as such did not justify the adoption of provisions in breach of fundamental rights.

The Court noted that the budget deficit was associated with excessively generous parental allowances and inappropriately regulated sickness benefits (leading to overcompensation in some cases). Moreover, there had been an outflow of large amounts of social security funds to social groups that cannot be deemed as disadvantaged or low-income.

The Court did not discuss the nature of the Stand-By Arrangement and Memorandum of Understanding and avoided qualifying them as international treaties. It rather focused on the constitutional division of powers. ${ }^{112}$

In relation to the competence to conclude agreements on state loans, the Court noted:

[The] principle of separation of powers delimits the authority of the Cabinet of Ministers. In accordance with this principle, the Constitution confers the lawmaking powers - namely, the powers to decide the most important matters for the state - to the Saeima in particular, and, in individual cases, to citizens of the Republic of Latvia. ... Although the Cabinet of Ministers is entitled to adopt regulatory enactments, the latter are not permitted to contain such provisions that cannot be deemed as aids for the implementation of the provisions of the law. ${ }^{113}$

Thus, the Saeima is obliged to decide all the most important matters of the State and public life by itself through legislation. Furthermore, the first part of Article 68 of the Constitution prescribes that all international agreements, which settle matters that may be decided by the legislative process, shall require ratification by the Saeima. ${ }^{114}$

the drafting of the Disbursement Law also because the budget deficit reduction had to be settled immediately. However, the Court established that other alternatives existed. See n. 98.

${ }^{111}$ See Judgment of the Constitutional Court in the Case No. 2009-43-01 of 21 December 2009 para. 30.1. At the same time, in para. 7.2 of the Supplementary Memorandum of Understanding between the European Community and the Republic of Latvia of 13 July 2009, Latvia pledged to reduce the pension expenditure by $10 \%$ for non-employed pensioners and by $70 \%$ for employed pensioners. With reference to the commitment between the IMF and the Republic of Latvia, the same pledge was included in the Economic Stabilisation and Growth Revival Programme for Latvia adopted by the Saeima on 16 June 2009 (para. 5.2). No evidence that the specific law was required by the IMF and the EU - for instance, in the negotiation minutes - was submitted to the Constitutional Court.

112 See Judgment of the Constitutional Court in Case No. 2009-43-01 of 21 December 2009 para. 30.1. See Mits 2013, pp. 28-29 for a more detailed analysis. See also Sects. 3.5 and 3.6 of this report.

113 Judgment of the Constitutional Court in Case No. 2009-43-01 of 21 December 2009, para. 30.1 .

${ }^{114}$ Ibid. 
Therefore, according to the Court, the budget is among the most important areas in which the Saeima exercises its parliamentary control over actions of the Government. Other institutions can take decisions that decisively affect the state budget only in the cases provided in the Satversme or if consent is given by the Saeima and the fundamental principles of a democratic state are observed. ${ }^{115}$

The Constitutional Court recognised that the matters dealt with by the Cabinet of Ministers in order to enter into the respective commitments with the international creditors were sufficiently important for the state and public life to be decided through legislation by the Saeima. ${ }^{116}$ The Constitutional Court maintained that the fundamental decision to take an international loan and the terms and conditions thereof are to be deemed as an important and significant matter of state and public life, and that, in accordance with the procedure established by the Satversme, they must be decided by the legislator. According to the Court, the Cabinet of Ministers cannot restrict fundamental rights enshrined in Art. 109 of the Constitution by assuming international obligations. The Saeima is still under an obligation to provide authorisation for the Government in matters of such fundamental importance. This authorisation can be given post factum. A decision of the Saeima is only required if an agreement is recognised as an international treaty in the meaning of Art. 68(1) of the Satversme. In other cases the Saeima is free to choose the form of authorisation. $^{117}$

The Constitutional Court established that neither the Cabinet of Ministers nor the Saeima had conducted an objective and well-weighed analysis regarding the consequences of the adoption of the impugned provisions or regarding other, less restrictive means for the attainment of the legitimate end. The annotation to the Draft of the Disbursement Law also indicates that no consultations with experts ever took place.

This led the Court to conclude that no alternatives were properly considered, for it was simply impossible to draft other adequate proposals in such a short period of time. Similarly, it was impossible to give careful and detailed consideration to such major issues as the potential economic effect and social consequences of these alternative solutions within the space of a few days. ${ }^{118}$ Consequently, the

\footnotetext{
115 Judgment of the Constitutional Court in Case No. 2011-11-01 of 3 February 2012, para. 10.

${ }^{116}$ See, however, the Letter of the Minister for Justice of the Republic of Latvia to the European Commission, Annex 3 to the Loan Agreement between the European Community and the Republic of Latvia of January 2009. In his letter the Minister formally noted that the commitments entered into by Latvia are taken in accordance with the Satversme. http://ec.europa.eu/latvija/ documents/pievienotie_faili/29.01.09.1a.doc.

${ }^{117}$ Mits 2013, p. 30. This interpretation has been subsequently confirmed by the Saeima. The Court itself remains very general in the judgment about the form of authorisation required, with Mits describing the alternatives that the Saeima can use according to guidelines provided by the Court. These are an announcement indicating the international lenders' restrictions on the amount of the loan and its spending, or a report by the Minister of Finance explaining the provisions of the loan.

${ }^{118}$ It is acknowledged in the legal doctrine that delay, unpredictability and inconsistency in the exercise of state power prove that measures carried out and implemented by the state have led to a
} 
Constitutional Court had no grounds to deem the alternative solutions - which lacked the necessary justification and analysis of economic and social consequences - to be sufficiently well-considered alternatives to the impugned provisions. ${ }^{119}$

The ESM Treaty There was debate whether a referendum was needed for ratification of the Treaty Establishing the European Stability Mechanism (ESM Treaty), in which experts were involved. ${ }^{120}$ The experts concluded that the role of the European Commission had been strengthened but that it had not been accorded new competences and its powers were limited to making recommendations and suggestions. Further, the competences of the CJEU did not exceed those set out in the TEU and TFEU. Experts also concluded that Latvia had already transferred competences to the EU in the area of economic policy upon ratifying the Lisbon Treaty. Moreover, Art. 2 of the ESM Treaty provides that it is applicable in line with EU Treaties. ${ }^{121}$ Therefore, the experts found that there were insufficient arguments to conclude that the ESM represents substantive changes in the conditions of Latvia's membership in the EU and, consequently, the Saeima could ratify the Treaty without calling for a referendum. Ultimately, a political compromise was reached with the opposition parties, and the Treaty was ratified according to Art. 68(2) of the Satversme. No further debates have taken place. ${ }^{122}$

\subsection{Judicial Review of EU Measures: Access to Justice and the Standard of Review}

2.8.1-2.8.6 The Constitutional Court has never requested a preliminary ruling from the CJEU. Nevertheless, the Constitutional Court has referred to EU law and the case law of the CJEU often, especially in environmental cases. It can be argued that the position of the Court is that the different systems can overlap and interact,

\footnotetext{
violation of the principle of proportionality - see Harris et al. 2009, p. 676. The ECtHR has also stated that 'uncertainty - be it legislative, administrative or arising from practices applied by the authorities - is a factor to be taken into account in assessing the State's conduct. Indeed, where an issue in the general interest is at stake, it is incumbent on the public authorities to act in good time, in an appropriate and consistent manner' (Broniowski v. Poland [GC], no. 31443/96, § 151, NS 184, ECHR 2004-V.

${ }^{119}$ Constitutional Court Judgment in Case No. 2009-43-01 of 21 December 2009. See also the Amendment to the Law on State Pension and State Allowance Disbursement in the Period from 2009 to 2012 adopted on 17 September 2009 and the annotation to this draft law http://titania. saeima.lv/LIVS/SaeimaLIVS.nsf/0/CDF73564B79BB4E3C225761F004BE61E?OpenDocument.

${ }^{120}$ See Opinion of the Council of Independent Experts on International and European Law on the question of the Treaty on stability, co-ordination and management in economic and monetary union from the point of view of EU law and the Satversme, 20 March 2012. Available in Latvian at http://www.mfa.gov.lv/nep-atzinums\%20nr\%201-20-mar-2012.pdf.

${ }^{121}$ It should be noted that the expert analysis was to a large extent similar to the analysis by the CJEU in Case C-370/12 Pringle [2012] ECLI:EU:C:2012:756.

${ }^{122}$ See also Sect. 3.5 .
} 
without mutual hierarchical subordination. ${ }^{123}$ On two occasions the Court has verified the necessity to submit a request for a preliminary ruling to the CJEU. In case No. 2008-47-01, the Court acknowledged that the provisions of Directive 2005/60/EC (the Third Money Laundering Directive) are sufficiently clear and there are no doubts about their interpretation (acte clair). In case No. 2010-71-01, the Court concluded that the outcome of the case would not depend on the interpretation of the Directive in question. ${ }^{124}$

However, both the Administrative and Civil Law Departments of the Supreme Court have asked for preliminary rulings on a number of occasions. According to the Ministry of Justice, as of 25 August 2014, Latvian courts have requested 32 preliminary rulings. Most of the cases have concerned the following areas: co-operation in civil matters, customs, Justice and Home Affairs, taxes (including the activities of the State Revenue Service - 16 cases) and social policy. In addition, the Government has intervened in several cases such as the Sugar Saga cases, a case on notaries and cases on EU citizenship.

The general position of the Constitutional Court is that: (a) Latvia should observe its international obligations and (b) Latvia is allowed to offer a higher standard of protection of fundamental rights.

In terms of data regarding constitutional review by the Latvian Constitutional Court, in total 246 judgments have been adopted by the Court from its establishment in 1996 until 21 August 2014. As noted above, about $80 \%$ of the case law of the Constitutional Court of Latvia concerns Chapter 8 on fundamental rights. One of the main grounds for review is the right to a fair trial (access to justice) set out in Art. 92 of the Satversme. The constitutionality of a norm in relation to Art. 92 has been reviewed in 48 Constitutional Court judgments as of 21 August 2014. Only Art. 91 (equality and non-discrimination) has served as a basis more frequently, in 81 judgments. The third most frequently invoked ground is Art. 105 (property rights), which has been under consideration in 45 cases. Further, as noted above, in more than one-half of the individual applications that refer to Art. 1, reference has been made to the principle of legitimate expectations in combination with some other fundamental right.

The question remains to what extent the accession of the EU to the ECHR would affect national case law. The precise conditions for the EU's accession to the ECHR remain uncertain, especially in the context of the division of competences between the CJEU and the ECtHR. Therefore, it is difficult to come up with a conclusive answer on whether the governments acting within the EU framework would be under a shield. Moreover, one should also closely follow further developments initiated by the Commission on extensive fundamental rights monitoring in all EU Member States. ${ }^{125}$

\footnotetext{
${ }^{123}$ MacCormick 1993, p. 9.

${ }^{124}$ Judgment of the Constitutional Court in Case No. 2008-47-01 of 28 May 2009, para. 15.2 and No. 2010-71-01 of 19 November 2011, para. 24.

${ }^{125}$ European Commission presents a framework to safeguard the rule of law in the European Union, 11 March 2014, IP/14/237. Available at http://europa.eu/rapid/press-release_IP-14-237_en. htm.
} 
As argued by Nollkaemper, to the extent that international law becomes part of the European legal order, the application of 'Europeanised' rules of international law is no longer only a function of the combination of weak principles of international law and constitutional law, but becomes a matter of EU law proper, notably with a view to its uniform application and interpretation. ${ }^{126}$

This raises doubts whether national courts are the best agents to transpose European values in the domestic legal order. Nollkaemper suggests that a preliminary problem for considering national courts as an institutional force that can help to secure compliance is the fact that these courts are organs of the very critics that they are to control. ${ }^{127}$ Instead, in EU law the primary task for the courts is to ensure compliance, which should be distinguished from implementation and enforcement.

\subsection{Other Constitutional Rights and Principles}

2.9.1 No further significant issues have arisen in Latvia with regard to constitutional rules and EU law.

With regard to systemic aspects in the protection of fundamental rights and the rule of law in the EU Member States, the following further observations are of relevance. The procedurally limited possibilities to apply Art. 2 TEU and Art. 7 TEU as well as Art. 51 of the Charter of the Fundamental Rights to purely internal situations raises the role of the national courts especially in areas that do not fall within EU competence but where there is a risk of violation of fundamental rights.

The question remains to what extent the EU is entitled to carry out such human rights monitoring. The EU remains procedurally ill-equipped to monitor respect of the fundamental values on which it prides itself on being based. ${ }^{128}$ As argued by Sarooshi, it is true that a state that transfers its powers to an international organisation does not confer its powers in toto on the organisation. The precise degree is difficult to measure. ${ }^{129}$ The difficulty in finding the right balance lies in finding the right relationship between the EU institutions, the CJEU and national constitutional courts.

The comparative studies conducted so far reveal that although the procedural powers, modes of legal reasoning and conceptions of the role of the judiciary in the constitutional system vary, the judiciaries of various EU Member States have so far reacted similarly to the reforms of the EMU, by significantly expanding their powers to review and even to pronounce certain measures as void. ${ }^{130}$ Therefore,

\footnotetext{
126 Nollkaemper 2012, p. 159.

127 For a critical assessment see Nollkaemper 2012, pp. 162-168.

${ }^{128}$ Editorial Comments, 'Fundamental rights and EU membership: Do as I say, not as I do!' (2012) CML Rev. 49, 481-488, 487-488.

129 Sarooshi 2007, pp. 69 and 120-122.

${ }^{130}$ Fabbrini 2014, pp. 103-104.
} 
there is no risk that the new measures adopted under the intergovernmental approach might affect the competence of national judiciaries.

At the same time, some scholars claim that judicial involvement in the fiscal domain raises a number of constitutional concerns. Federico Fabbrini argues that political branches have greater expertise and instrumental capacity than courts to make decisions in fiscal matters. Political process is better able to represent the voice of the people. Although the EU needs to improve its legitimacy and democracy, this requires elaborating the accountability of the EU political process, rather than increasing review and interference by courts. ${ }^{131}$

Other authors claim that the crisis which hit the EU was not only financial but, most importantly, it touched upon the functioning principles of the Union as set out in Art. 2 TEU, including the principle of the rule of law. For instance, Cesare Pinelli convincingly argues that the values mentioned in Art. 2 TEU are based on the presumption that they are common to the Member States and constitute the foundation of the EU. ${ }^{132}$ Commentators attribute great importance to weakness in the rule of law for the extent of the economic crisis. Due to endemic corruption, weak institutional capacities or insufficient resources at the administrative or judicial levels, compliance with EU standards is seriously questioned. ${ }^{133}$ Commentators have addressed the issue of systemic deficiency in the rule of law. Public authorities must act in accordance with constitutional norms, including fundamental rights, and general rules that have been laid down by superior organs, usually a parliament. The deficient rule of domestic law automatically translates into a deficient rule of EU law. ${ }^{134}$ In this context, creating a mechanism for establishing the concept of systemic deficiency neither creates new obligations for the Member States nor expands the EU's field of action. ${ }^{135}$

There have already been a number of proposals tabled for appropriate mechanisms, such as reinvention of the 'Copenhagen Criteria', ${ }^{136}$ and introducing a more comprehensive co-operation and verification mechanism, following the practice of

${ }^{131}$ Ibid., pp. 104-105.

132 Pinelli 2012, p. 8.

${ }^{133}$ Von Bogdandy and Ioannidis 2014, pp. 59 and 75. See also (2013, October 4) EU seeks greater role in policing national democracies. The Oxford Analytica Daily Brief; and Butler 2012.

${ }^{134}$ Von Bogdandy and Ioannidis 2014, pp. 63-64.

135 See von Bogdandy and Ioannidis 2014, pp. 63-64 and 67, and von Bogdandy et al. 2012, pp. 507-508. In certain cases domestic fundamental rights violations would come within the ambit of Union law. Those would be cases where violations would affect the 'substance of EU citizens' rights', thus depriving the substance of its practical meaning (substance of rights according to C-34/09 Ruiz Zambrano [2011] ECR I-01177).

${ }^{136}$ See Ralli, E. (2014, January 14). Proposal for a new 'Copenhagen mechanism' to ensure compliance with EU values and accession criteria. New Europe. http://www.neurope.eu/article/ meps-set-enhance-protection-human-rights. See European Union Agency for Fundamental Rights, Annual report 2013, 'An EU internal strategic framework for fundamental rights: joining forces to achieve better results', pp. 7-20. http://fra.europa.eu/sites/default/files/annual-report-2013-focus en.pdf and supra n. 125. For critical remarks on the lack of ongoing human rights monitoring, see Albi 2009, p. 47. 
the World Bank and the IMF which make access to their funds contingent upon building more efficient state institutions, and which would be capable of generating confidence in the rule of law. ${ }^{137}$

As noted by Oscar Schachter, the critical fact is that so far, states alone have provided the structures of authority needed to cope with the claims of competing societal groups and to provide the public justice that is essential to social order and responsibility. ${ }^{138}$ In general, there is a deficit of common institutions which could ensure equal protection of the law above the national level. Therefore, there is an inevitable need for multi-issue transnational regulation in the EU.

\subsection{Common Constitutional Traditions}

2.10.1-2.10.2 The Constitutional Court has referred to common constitutional traditions on several occasions. For instance, in a case on elections, it referred to the Code of Good Practice in Electoral Matters adopted by the Venice Commission. The notion has further been used to interpret Art. 101 of the Satversme. ${ }^{139}$

The Constitutional Court has also referred to common EU values in environmental cases. For instance, it has stated that:

According to European Union law, obligations of Latvia regarding conservation of the
environment are a part of the common responsibility of the Member States, because the
nature of Latvia is a part of the common heritage of the entire European Community. Latvia
has no legal basis to make alterations to these territories, because this would hinder
attainment of the objectives established in the directives of the European Union ....

For the purposes of this project it may be noted that the independence of the judiciary is a general principle of law, as all major legal systems appear to formally embrace the principle. ${ }^{141}$ Respect for this principle is also crucial for ensuring that the principle of the rule of law is preserved at both EU and national level.

It should be noted that there are differences between the constitutional traditions of EU Member States. Even where common terminology is used, the meaning of the terms may be different. Moreover, rulings of the ECtHR have demonstrated that there may be conflicts between national courts and the ECtHR. Therefore, the broad

\footnotetext{
${ }^{137}$ Von Bogdandy and Ioannidis 2014, pp. 63-64 and 87-88. Something resembling this is currently provided in the European Financial Stability Facility and the European Stability Mechanism.

${ }^{138}$ Schachter 1998, pp. 22-23.

${ }^{139}$ See Judgment of the Constitutional Court in Case No. 2009-45-01 of 22 February 2010, para. 9. See also http://www.venice.coe.int/webforms/documents/?pdf=CDL-AD(2002)023rev-e.

140 Judgment of the Constitutional Court in Case No. 2007-11-03 of 17 January 2008, para. 25.4, with extensive references to CJEU case law in this field.

${ }^{141}$ Nollkaemper 2012, p. 167.
} 
concepts enshrined in Art. 2 TEU represent a challenge for the EU in terms of finding exact definitions in the future.

\subsection{Article 53 of the Charter and the Issue of Stricter Constitutional Standards}

2.11.1 As noted above in Sect. 2.7, the Constitutional Court has concluded that international norms do not prohibit the establishment of a higher level of protection at the national level.

According to Art. 89 of the Satversme, the state protects human rights in accordance with the Satversme, laws and international treaties binding for Latvia. The Court has concluded that this provision aims at achieving harmony between the provisions of the Satversme and international human rights obligations. ${ }^{142}$ The protection offered by the Satversme cannot be lower than that derived from international instruments, as this would violate the principle of the rule of law enshrined in Art. 1 of the Satversme. Therefore, when interpreting the Satversme, a harmonious solution should be sought. ${ }^{143}$ In addition, it should be borne in mind that the Satversme can provide a higher protection of human rights than international human rights instruments. ${ }^{144}$

The possibility of conflicts between norms under different regimes is inevitable. The EU Treaties form a special regime in international law, and they are subject to a generally accepted principle that when several norms bear on a single issue, they should, to the extent possible, be interpreted so as to give rise to a single set of compatible obligations. ${ }^{145}$ The role of national courts in this context appears to be that of agents of compliance. This is best developed in the so-called transnational legal process theory, which in its explanation of compliance attributes considerable weight to the extent to which international law is incorporated in domestic legislation and given effect in the domestic courts. Apart from EU law, internal focus is particularly present with regard to human rights law. ${ }^{146}$

It should also be noted that in certain cases, the EU offers a higher level of protection than national courts or the ECtHR. According to the Treaties, the CJEU

\footnotetext{
${ }^{142}$ For instance, Judgments of the Constitutional Court in Cases No. 2003-04-01 of 27 June 2003, para. 1; and No. 2004-10-01 of 17 January 2005, para. 7.1.

${ }^{143}$ Judgment of the Constitutional Court in Case No. 2004-18-0106 of 13 May 2004, para. 5.

144 Judgments of the Constitutional Court in Cases No. 2001-06-03 of 22 February 2002, para. 3; and No. 2005-02-01-6 of 14 September 2005, para. 10.

${ }^{145}$ For definitions and groupings of special regimes see Fragmentation of International Law: Difficulties Arising from the Diversification and Expansion of International Law, International Law Commission, 58th session (13 April 2006) UN Doc A/CN.4/L.682, 65-101. and Conclusions of the work of the Study Group on the Fragmentation of International Law: Difficulties arising from the Diversification and Expansion of International Law (2006), UN Doc A/61/10, para. 251. ${ }^{146}$ Nollkaemper 2012, pp. 164-165.
} 
should ensure that it preserves its role as the core guardian ensuring observation of the rule of law in the EU. In this context, for instance cases related to citizenship and immigration show the potential of EU law to address issues in a more efficient way. ${ }^{147}$ The same can be said about market-related cases where service providers and companies move across borders. ${ }^{148}$

In the context of the protection of fundamental rights, the national context should also be taken into account. For instance, from the Latvian perspective, at least two rulings of the ECtHR have been doubtful due to their insensitivity to the national legal situation. The courts should remain mindful of the specific circumstances of the cases before them from a historical and legal point of view. ${ }^{149}$

Therefore, international courts not only face the problem of establishing their standards, but they should remain mindful of national and historical circumstances when evaluating each particular case. This makes the task of identifying common traditions and standards even more difficult.

\subsection{Democratic Debate on Constitutional Rights and Values}

2.12.1-2.12.3 Debates on constitutional values took place recently when the Saeima adopted the Preamble to the Constitution in 2014. ${ }^{150}$ Although the Preamble mentions respect for human rights and the rights of minorities, it also emphasises that the Latvian identity has since ancient times been shaped by Latvians and Livs, and includes the Latvian language and human and Christian values. It also mentions freedom, equality, justice, work and family as the foundations of society. Reference to democratic development in Europe is also included.

If it were to happen that serious constitutional rights and values were affected by EU law, the Constitutional Court would have several options to reconcile any infringement of the Satversme with the risk of sanctions under the EU regime. First, the Court could request a preliminary ruling. Secondly, in our view, the Court could remedy the situation by interpretation and thirdly, it could rule that the national provision will lose its force at a future date.

In principle, the recommendation in the Questionnaire to suspend the application of EU measures if important constitutional issues have been identified by a number of constitutional courts, could be supported. However, the mechanism for

\footnotetext{
${ }^{147}$ The EU citizenship cases are well established, from e.g. Case C-184/99 Grzelczyk [2001] ECR I-06193 to the more recent Case C-34/09 Zambrano [2011] ECR I-01177.

${ }^{148}$ For instance, Case C-341/05 Laval [2007] ECR I-11767.

${ }^{149}$ See also Sect. 2.13. In the Latvian context, see Case of Slivenko v. Latvia [GC], no. 48321/99, ECHR 2003-X and Case of Andrejeva v. Latvia [GC], no. 55707/00, ECHR 2009. For details see Krūma 2014, pp. 392-395.

${ }^{150}$ The debates were reported by the weekly legal journal Jurista Vards, 8 July 2014, and 22 October 2013.
} 
implementation of such a recommendation remains unclear. Moreover, the very existence and competence of the constitutional courts and constitutions vary. If such a recommendation is proposed, it should be focused and limited.

As noted in the results of a project led by Ronald Inglehart, the identification of values requires a detailed analysis which illustrates that people's beliefs play a key role in economic development, the emergence and flourishing of democratic institutions, the rise of gender equality and the extent to which societies have effective government. ${ }^{151}$ Therefore, if the EU is serious about identifying the content of the common constitutional values, a comprehensive exercise to determine the correct interpretation of the values mentioned in Art. 2 TEU is required.

\subsection{Experts' Analysis on the Protection of Constitutional Rights in EU Law}

2.13.1-2.13.4 The question on the overall standard of protection is complex for a number of reasons. As argued by De Witte, the CJEU may decide to privilege the right to property, whereas one or another national court may want to give greater weight to the opposed right to privacy (or vice versa), and it is impossible to decide which of the courts is then offering a higher protection to fundamental rights. ${ }^{152}$

In order to break away from domestic concepts, the best way forward for the Union would be to develop its own sovereign values that would be attached to the exercise of transferred sovereign powers. ${ }^{153}$ In our opinion, the role of the EU should become stronger to ensure that the standard of protection of fundamental rights and the rule of law are not reduced in particular Member States. This has already incited a reaction from different EU institutions, including the CJEU, and academic literature. The focus is on the need to strengthen the EU's ability to intervene in purely internal situations in order to protect fundamental rights.

The most recent crisis situations in 2012 in different EU countries were not limited to the fields of employment or economic policies in general, but also concerned the political systems; social unrest, public protests, anti-migrant initiatives by political parties, decreasing trust in government or neighbouring states and violent expressions of extremist ideology were quite widespread. ${ }^{154}$ There are areas in which some Member States have experienced setbacks in human rights

${ }^{151}$ See Values Change the World. World Values Survey. http://www.iffs.se/wp-content/uploads/ 2012/12/WVS-brochure-web.pdf.

${ }^{152}$ De Witte 2009, p. 44.

${ }^{153}$ Sarooshi 2005, p. 74. On the EU value system, see also Nijman and Nollkaemper 2007, p. 346.

${ }^{154}$ European Union Agency for Fundamental Rights (FRA), Fundamental rights: challenges and achievements in 2012, Annual Report 2012. Luxembourg 2013, pp. 19-22. See also (2013, October 4) EU seeks greater role in policing national democracies. The Oxford Analytica Daily Brief; and (2013, May 20) Hungary may prompt greater monitoring of democracy in EU. The Oxford Analytica Daily Brief. 
protection, such as the controversial treatment of Roma, limitations on media freedom, discrimination of migrants in some of the new Member States, growing radicalism in Europe and the like. ${ }^{155}$ Neither the constitutional courts nor any other courts have been able to offer sufficient mechanisms to cope with these systemic problems.

It should also be noted that there are certain rights for which the EU provides much higher protection than the ECtHR. One area which stands out is the right to family reunification and the rights of third country nationals who are long term residents. ${ }^{156}$

\section{Constitutional Issues in Global Governance}

\subsection{Constitutional Rules on International Organisations and the Ratification of Treaties}

3.1.1-3.1.4 The rules of the Satversme and the relevant procedures have been explained in Part 1. In addition, the rules on the ratification of international treaties have been spelt out in the Law on International Treaties, while the hierarchy of sources of law is provided for in the Law on Administrative Procedure.

It is commonly thought that one of the key differences between EU law and public international law is that while in public international law the effect of a norm in the national legal order is determined by national law instead of international law, in EU law such effect is a matter of EU law instead of national law. ${ }^{157}$

\subsection{The Position of International Law in National Law}

3.2.1-3.2.2 The classification of monism and dualism is not of major importance in Latvia. Scholars have rightly classified the Latvian case as de facto monism. The

\footnotetext{
${ }^{155}$ In relation to Hungary, see Editorial Comments, 'Fundamental rights and EU membership: Do as I say, not as I do!' CML Rev. (2012) 49, 481-488, 486. Pinelli 2012, p. 5. In relation to migrant workers see articles in the volume Isin and Saward 2013. Useful information on different human rights violations is also available on the website of the European Commission against Racism and Intolerance, available at http://www.coe.int/t/dghl/monitoring/ecri/activities/countrybycountry_en. asp. In relation to the Cooperation and Verification Mechanism for Bulgaria and Romania, see FRA Annual Report 2012, n. 154, pp. 22-23. See also European Agency for Fundamental Rights (2013) Racism, intolerance, discrimination: learning from experiences in Hungary and Greece, FRA Thematic Situation Report. http://fra.europa.eu/en/publication/2013/racism-discriminationintolerance-and-extremism-learning-experiences-greece-and. See also Nielsen, N.J. (2014, January 15) Radicalism on the rise in Europe, EU commissioner says. EU Observer. http://euobserver.com/ justice/122735.

${ }^{156}$ See for instance, Biao v. Denmark, no. 38590/10, 25 March (appealed to the Grand Chamber).

${ }^{157}$ Nollkaemper 2012, p. 168.
} 
Satversme does not deal with issues of hierarchy. Domestic laws refer to situations of collision between international and national law, but judges tend to prefer to apply international law. ${ }^{158}$

It should be noted that the general approach adopted by the Constitutional Court is one of consistent interpretation. The practice of consistent interpretation has great potential to secure compliance with European and international obligations. ${ }^{159}$

The Latvian Constitutional Court supports the principle that national law should be interpreted in line with Latvia's international obligations. This also corresponds to the requirements of international law. In certain cases the Constitutional Court has recognised the direct effect of norms of international law. ${ }^{160}$ The Court has stated that the text of the ECHR and the practice of ECtHR serve as means of interpretation on the level of constitutional law to determine the content and the scope of fundamental rights and the principle of the rule of law. ${ }^{161}$ The Court further has directly applied the International Convention on Elimination of Racial Discrimination, the International Covenant on Civil and Political Rights and the UN Convention on the Rights of the Child.

As argued by Nollkaemper, it appears that there remain fundamental differences between EU law and international law with respect to the principles that underlie the compliance-inducing role of national courts. The principles of EU law, with regard to supremacy, direct effect, consistent interpretation and state liability are more developed, more powerful and more embedded in national law. ${ }^{162}$ In this context, the EU has strengthened international law by proclaiming that its rules are binding for the EU. ${ }^{163}$ Therefore, even if the Member States have been reserved in the application of international law, the EU is bringing international law into its scope of application. In this context, as Nollkaemper argues, international law becomes Europeanised.

The provisions of treaties and decisions of international organisations that are part of the legal order of the EU can acquire direct effect as defined by EU law, not international law. However, treaties are not entirely equated to internal EU rules, and the principle of direct effect as it applies to treaties is not identical to the principle as it applies to internal rules. ${ }^{164}$ The CJEU itself has proclaimed that EU law should be interpreted in conformity with international law. ${ }^{165}$

\footnotetext{
158 Mits 2006, p. 429.

159 Nollkaemper 2012, p. 180.

160 See Case No. 2004-18-0106 of 13 May 2005, para. 5. See also Nollkaemper 2012, pp. 178 179.

${ }^{161}$ See Judgment of the Constitutional Court in Case No. 2000-03-01 of 30 August 2000, para. 5 and Case No. 2001-08-01 of 17 January 2002, para. 3.

162 Nollkaemper 2012, p. 188.

163 See Case C-286/90 Anjkagemyndigheden v. Poulsen and Diva Navigation [1992] ECR I-06019.

164 Nollkaemper 2012, pp. 190-191. See also Case C-300/98 Dior and Others [2000] ECR I-11307, Case C-308/06 Intertanko and Others, [2008] ECR I-04057.

165 Case 286/90 Anjkagemyndigheden v. Poulsen and Diva Navigation, supra n. 163.
} 
It has been noted that 'the cause of the weak position of general international law is a very significant diversity in the practices of states'. ${ }^{166}$ This raises the question not only of the compatibility of national law with international and EU law, but also to what extent national law is capable of accommodating modern day realities, including the need of individuals to move and reside across borders.

\subsection{Democratic Control}

3.3.1-3.3.2 According to the Satversme, referendums on international treaties are not allowed. The role of the Saeima is important; however, in practice the executive branch has more competence and knowledge. The position of the Constitutional Court is cautious, depending on the case at stake. ${ }^{167}$

The question remains as to the form in which the delegation of powers takes place. In this context, there is a difference to be drawn between the inter-governmental and Community/Union methods. Under the first, national institutions still preserve substantive competence to authorise ratification.

\subsection{Judicial Review}

3.4.1 There have been no cases in which the Latvian courts have reviewed international measures directly. However, there have been cases where either the Constitutional Court or the legal doctrine have disagreed with the rulings of international bodies because they failed to respect national particularities. ${ }^{168}$

The Latvian Constitutional Court took the lead in ensuring a smooth accession and the interpretation of national law in accordance with EU law already before accession. Art. 32(3) of the Law on the Constitutional Court provides that a contested norm loses its force upon adoption of a ruling declaring the norm to be unconstitutional. The law also allows the Court to decide on the moment at which the norm will lose its force, for which reasons must be provided. The Court has pronounced that it should ensure that its rulings bring about legal stability and clarity. ${ }^{169}$ This specifically applies in cases involving substantive financial resources. ${ }^{170}$

\footnotetext{
166 Nollkaemper 2012, p. 194.

${ }^{167}$ See, for instance, Judgment of the Constitutional Court in Case No. 2008-35-01 of 7 April 2009, available at http://www.satv.tiesa.gov.lv/upload/spriedums-2008-35-01_ENG.pdf.

168 See for instance Slivenko v. Latvia, supra n. 149, and Andrejeva v. Latvia, supra n. 149. See also Communication No. 1621/2007, Raihman v. Latvia, CCPR/C/100/D/1621/2007, 30 November 2010.

169 See Judgment of the Constitutional Court in Case No. 2009-43-01 of 21 December 2009, para. 35.1. and Judgment of the Constitutional Court in Case No. 2002-04-03 of 22 October 2002, para. 3.

${ }^{170}$ For instance, Judgment of the Constitutional Court in Case No. 2010-44-01 of 20 December 2010, para. 17, Case No. 2012-22-0103 of 27 June 2013, para. 19.
} 


\subsection{The Social Welfare Dimension of the Constitution}

3.5.1-3.5.2 The Latvian austerity programme can be considered an IMF success story. During the peak of economic growth in 2005-2008, the Government had taken a number of decisions to the detriment of long-term economic development. Even during the economic crisis, certain important structural reforms were not implemented, e.g. in the education, health, tax and other sectors. During the time of the crisis in 2008-2011, the IMF and the European Commission helped Latvia overcome the most immediate economic problems. ${ }^{171}$ It should also be noted that international organisations gave Latvia a timely warning that its economic policies would raise the risk of poverty in Latvia and called for this problem to be dealt with as soon as possible. ${ }^{172}$

The main reason why the Constitutional Court questioned the IMF negotiation records, which was explored in greater detail in Sect. 2.7, was not because it was concerned about a lack of transparency on the IMF side, but rather because there was a lack of objective information from the Government on the scale of the crisis.

The Court referred to a number of studies which had indicated that there were shortcomings in the planning of state finances. The Court noted that several organisations had assessed the risk of poverty for the residents of Latvia. ${ }^{173}$ Even during the time of economic growth, the funds allocated to social protection services were relatively scant in Latvia. Notably, the poverty risk among elderly people increased even during the time of economic growth. ${ }^{174}$ However, the Court's mandate did not allow for it to intervene or to revise the macroeconomic approach and budget formation.

Thus, it has rightly been noted that the root causes of the crisis lay in unsustainable public finances. One of the main reforms adopted by both the Member States and the EU institutions since 2009 has been the introduction of tighter budgetary constraints. This approach was adopted already in the Stability and Growth Pact of 1997. The eruption of the euro crisis and the complex interconnection between sovereigns and banks revealed that it was easier on paper than in reality to let a country of the eurozone default without this producing a systemic

\footnotetext{
${ }^{171}$ It should be noted, however, that the economy started to grow from 2010, but the EU and the IMF finalised their supervision only in 2014.

${ }^{172}$ On the timely signals from the World Bank see http://www-wds.worldbank.org/external/ default/WDSContentServer/WDSP/IB/2007/04/12/000020439_20070412105345/Rendered/PDF/ 384370LV.pdf. On IMF warnings earlier in 2012 see (2012, February 15) More people at risk of poverty - IMF report. The Baltic Times. http://www.baltictimes.com/news/articles/30601/.

${ }^{173}$ For example, Eurostat data of poverty risk groups due to old age for the year 2007 show that approximately $33 \%$ of persons over 65 are in the poverty risk group. See http://ec.europa.eu/ employment_social/spsi/docs/social_inclusion/data_overarching_en.xls.

${ }^{174}$ Survey of European Union Statistics on Income and Living Conditions (EU-SILC). http:// www.csb.lv/csp/content $/$ cat $=471 \& i d=5762$. See also Europe in Figures, Eurostat yearbook 2009, p. 256; Inequality of income distribution. http://epp.eurostat.ec.europa.eu/tgm/table.do?tab= table\&init $=1 \&$ plugin $=1 \&$ language $=$ en \&pcode $=t \operatorname{sdsc} 260$.
} 
effect on the stability of the eurozone as a whole. Hence, the EU institutions and the Member States endowed themselves with new mechanisms to face this challenge. ${ }^{175}$ It should also be noted that the new mechanisms are based in the so-called intergovernmental rather than Community method, and the European Stability Mechanism is modelled on the International Monetary Fund. Thus, the inter-governmental approach has shown that the IMF model is suitable for controlling budget planning by the Member States.

\subsection{Constitutional Rights and Values in Selected Areas of Global Governance}

3.6.1 No major issues beyond those discussed in other parts of the report have arisen in Latvia.

\section{Concluding Remarks}

Human rights, including the rights of EU citizens, form an increasingly significant element of the EU's legal architecture. Article 2 of the TEU proclaims that the EU is founded on the common values of the Member States, i.e. respect for human dignity, freedom, democracy, equality, rule of law and respect for human rights, including minority rights. This was further strengthened by the Charter of Fundamental Rights becoming an integral part of the EU Treaties.

The fact that either part of the sovereignty or part of the national competences of the Member States has been delegated to the EU is a truism. However, this has not yet been confirmed by all of the Member States' constitutions and there is also no answer as to what consequences this has for the institutions which claim to have acquired these competences. The search for a definition of democracy at the EU level is not a new endeavour. ${ }^{176}$ The need for a re-definition of supranational democracy has also been highlighted by legal scholars. For instance, the dynamics of the EU suggest that nationalism could gradually be replaced by so-called constitutional patriotism as suggested by Habermas. This entails the facilitation of solidarity between strangers. Values rooted in culture and history on the one hand, and judicial and political values on the other, should be set in balance. The procedural order in the EU should remain neutral to national identity and morality. Habermas rightly considers that a European constitutional patriotism could grow

\footnotetext{
${ }^{175}$ Fabbrini 2014, pp. 68, 70-71 and 104.

${ }^{176}$ For instance, Fossum and Eriksen have offered three models, i.e. delegated democracy, federal democracy or cosmopolitan democracy. See Krūma 2009, p. 145.
} 
out of the constitutional principles and traditions stemming from the European level. $^{177}$

Yet another direction of research has been highlighting the growing need to facilitate rules on the responsibility of international organisations. As argued in The Economist:

Some Europeans would like to put up carefully designed fences around the EU's still vast wealthy market. Others, including a growing number of populist politicians, want to turn their nations inward and shut out not just the world but also the elites' project of European integration. And a few - from among those same elites, mostly - argue that the only means of paying for Europe's distinctive way of life is not to evade globalisation but to embrace it wholeheartedly. ${ }^{178}$

Discussion is warranted whether the level of national constitutions is really best suited for bearing responsibility for the actions of international organisations because the states have created them and provided them with the relevant powers. Therefore, this raises the question whether the primary focus should be on the effectiveness of national constitutions or the potential of international mechanisms.

In this context the framing of the questions is important. Are we discussing the 'erosion' of constitutionalism and 'waning' constitutionalism? Or are we rather embarking on the process of re-defining the meaning of sovereignty and democracy in a supranational or transnational context? The way in which the question is posed might change the perspective for providing answers.

Community law is 'successful international law, and ... is thus a possible horizon of international law, indicating the route that international law must follow if it is to move forward'. ${ }^{179}$ The need for comprehensive monitoring of the human rights situation has been advocated since the beginning of $2000 .^{180}$

The EU's Fundamental Rights Agency has correctly noted:

\begin{abstract}
Moreover, the political situation in the different EU Member States can no longer be seen as decoupled from that of their neighbouring states and the EU as a whole. Member States and the EU consist of an interdependent, semi-constitutional construction. In a system where judgments are handed down in one Member State but can automatically be executed in another, where asylum seekers are sent from state A to have their asylum procedure done in state B, or where persons are arrested in one Member State on the basis of an arrest warrant issued in another, the need for a shared set of core values is crucial in allowing all these mechanisms of exchange to be trustworthy. Against this backdrop, major challenges to the principles of democracy or the rule of law in one or more Member States are thus likely to have repercussions on the functioning of the EU as a whole. ${ }^{181}$
\end{abstract}

However, the question of the precise mechanisms and divisions of competencies remains. As long as Member States have a mistrust in the EU as an organisation

\footnotetext{
${ }^{177}$ Habermas 1995, pp. 255-281, as quoted by Guild 2004, p. 69.

178 (2011, November 12) Starting into the abyss. The Economist, p. 3.

${ }^{179}$ Leben 1998, p. 298 as quoted by Nollkaemper 2012, p. 158.

${ }^{180}$ De Witte 2003.

${ }^{181}$ For details see FRA Annual Report 2012, supra n. 154, p. 21.
} 
capable of offering a proper standard of protection of fundamental rights and national agendas prevail over EU objectives, an effective system will not be in place. Therefore, the primary task is to build on mutual trust and respect for commonalities rather than to push forward national agendas. After all, the EU has been created to benefit Europeans rather than to create harm for national democracies and identities. In this sense the EU is better placed to do away with national sentiments which sometimes are deeply rooted in nationalism, local political agendas and an inability to cope with long-needed structural reforms of governmental management in the globalised world.

The Latvian case has illustrated that in certain cases external monitoring is exactly what is needed for a country to succeed in the long term. Local political agendas are not always capable of responding to global challenges in an adequate way. This was the case when Latvia was in the process of joining the EU in relation to the Citizenship Law, Language Law and Education Law, and this had been the case before Latvia had to opt for the austerity measures to fix its financial problems and shortcomings in the rule of law. The courts alone, without external expertise, would not have been capable of solving these problems.

\section{References}

Albi A. (2009) Ironies in Human Rights Protection in the EU: Pre-Accession Conditionality and Post-Accession Conundrums. ELJ 15(1):46-69.

Aslund A., Dombrovskis V. (2011) How Latvia Came Through the Financial Crisis. Petersen Institute for International Economics, Washington.

Buka A. (2000) Par iespējamiem grozijjumiem mūsu Satversmē (On possible amendments to the Satversme). Jurista Vārds 23:176 et seq.

Butler I. (2012) The justice scoreboard: An effective mechanism to enforce respect for the rule of law? Open Society Foundation, 13 December 2012, http://www.opensocietyfoundations.org/ voices/justice-scoreboard-effective-mechanism-enforce-respect-rule-law.

De Witte B. (2003) The Impact of Enlargement on the Constitution of the European Union. In: Cremona M. (ed.) The Enlargement of the European Union. Oxford University Press, Oxford, pp. 229-238.

De Witte B. (2009) The Lisbon Treaty and National Constitutions. More or Less Europeanisation? In: Closa Carlos (ed.) The Lisbon Treaty and National Constitutions. Europeanisation and Democratic Implications, ARENA Report No. 3/09, RECON Report No. 9, pp. 25-48.

Fabbrini F. (2014) The Euro-Crisis and the Courts: Judicial Review and the Political Process in Comparative Perspective. Berkley Journal of International law 32(1):64-105.

Guild E. (2004) The Legal Elements of European Identity: EU Citizenship and Migration Law. Kluwer Law International, The Hague.

Habermas J. (1995) Citizenship and National Identity: Some Reflections on the Future of Europe. In: Beiner R. (ed.) Theorising Citizenship. SUNY, New York, pp. 255-281.

Harris D., O'Boyle M., Warbrick C., (2009) Law of the European Convention on Human Rights, 2nd edn. Oxford University Press, Oxford.

Isin E., Saward, M., (2013) Enacting European Citizenship. Cambridge University Press, Cambridge. 
Krūma K. (2004) Stocktaking of EU Pre-Accession Monitoring Process, Citizenship Issues and Non-citizens in Estonia and Latvia: a Litmus Test for European Union Human Rights Policy. Baltic YIL 4:33-53.

Krūma K. (2009) Constitutional Courts in the Europeanisation of National Constitutions. In Closa Carlos (ed.) The Lisbon Treaty and National Constitutions. Europeanisation and Democratic Implications, Arena Report No 3/09, RECON Report No.9, pp. 143-166.

Krūma K. (2014) EU citizenship, Nationality and Migrant Status. An Ongoing challenge. Martinus Nijhoff Publishers, Leiden and Boston.

Langa P. (2009) Taking Dignity Seriously: Judicial Reflections on the Optional Protocol to the ICESCR. Nordic Journal of Human Rights 27(1):29-38.

Leben C. (1998) Hans Kelsen and the Advancement of International Law. EJIL Vol. 9 (1998):287-305.

MacCormick N. (1993) Beyond the Sovereign State. MLR 56(1):1-18.

Mits M. (2006) Internationalisation of Public Law: the Case of Latvia. Revue Européenne de Droit Public 18(1):421-442.

Mits M. (2010) European Convention on Human Rights in Latvia. Impact on Legal Doctrine and Application of Legal Norms. Media Tryck, Lund University.

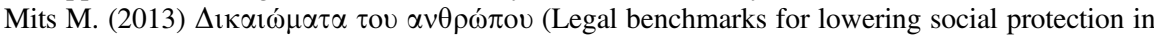

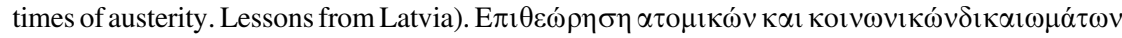
(Human rights: Theory of civic and social rights) 57:11-53.

Melkisis E. (2000) Latvijas Republikas Satversme un Eiropas Savieniba (The Satversme of the Republic of Latvia and the European Union). Likums un Tiesibas, 6:165-167.

Nijman J., Nollkaemper A. (2007) Beyond the Divide. In: Nijman J., Nollkaemper A. (eds.) New Perspectives on the Divide Between National and International Law. Oxford University Press, Oxford, pp. 341-360.

Nollkaemper A. (2012) The Role of National Courts in Inducing Compliance with International and European Law - a Comparison. In: Cremona M. (ed.) Compliance and the Enforcement of EU Law. Oxford University Press, Oxford, pp. 157-194.

Pinelli C. (2012) Protecting the Fundamentals: Article 7 of the Treaty on the European Union and Beyond. Foundation for European Progressive Studies. http://www.feps-europe.eu/assets/ 9a4619cf-1a01-4f96-8e27-f33b65337a9b/protecting\%20the\%20fundamentals.pdf.

Piqani D. (2012) The Role of National Constitutional Courts in Issues of Compliance. In: Marise C. (ed.) Compliance and the Enforcement of EU Law. Oxford University Press, Oxford, pp. 132-156.

Plaksins E. (2013) Eiropas Cilvektiesibu tiesas un Latvijas tiesu mijiedarbibas aktualitates (The importance of mutual co-operation between the European Court of Justice and National Courts). Bulletin of the Supreme Court 7:39-44.

Pleps J. (2003) Kāds ir konstitucionālais pamats mūsu dalībai Eiropas Savienībā (What are the constitutional bases for EU membership). Jurista Vārds 23 (281), 24 (282), pp. 8-11.

Sarooshi D. (2007) International Organizations and their Exercise of Sovereign Powers. Oxford University Press, Oxford.

Schachter O. (1998), The Decline of the Nation-State and its Implications for International Law. Colum. J. Transnat'L. 36 (7) A:7-23.

Skudra V. (2010) Parskats par Satversmes tiesas darbu starpkonferencu laika - 2009. un 2010. gada (Overview of the work of the Constitutional Court between the conferences in 2009 and 2010). Paper presented at the conference on 'Principle of Legitimate Expectations in the Case Law of the Constitutional Court', Daugavpils, Latvia, 10 September 2010.

Von Bogdandy A., Ioannidis M. (2014) Systemic Deficiency in the Rule of Law: What it is, What has been done, What can be done. CMLR 51:59-96. 
Von Bogdandy A., Kottmann M., Antpöhler C., Dickschen J., Hentrei S., Smrkolj M. (2012) Reverse Solange - Protecting the Essence of Fundamental Rights Against EU Member States. CMLR 49:489-520.

Ziemele I. (2004) Atsevišķu Latvijas Republikas Satvers grozījumu nepieciešamības pamatojums sakarā ar Eiropas Savienības tiesību integrāciju Latvijas tiesību sistēmā (Reasons for the need for certain amendments to the Satversme of the Republic of Latvia in view of the integration of EU law in the Latvian legal system). Likums un Tiesības 6(3):69-70.

Open Access This chapter is licensed under the terms of the Creative Commons Attribution 4.0 International License (http://creativecommons.org/licenses/by/4.0/), which permits use, sharing, adaptation, distribution and reproduction in any medium or format, as long as you give appropriate credit to the original author(s) and the source, provide a link to the Creative Commons license and indicate if changes were made.

The images or other third party material in this chapter are included in the chapter's Creative Commons license, unless indicated otherwise in a credit line to the material. If material is not included in the chapter's Creative Commons license and your intended use is not permitted by statutory regulation or exceeds the permitted use, you will need to obtain permission directly from the copyright holder.

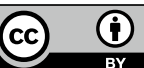

